\title{
CRUCIFIXOS EM REPARTIÇÕES PÚBLICAS: DO EXAME DE CONSTITUCIONALIDADE DE UMA PRÁTICA ADMINISTRATIVA BASEADA NA TRADIÇÃOO ${ }^{11}$
}

\author{
CRUCIFIXES IN PUBLIC OFFICES: ABOUT THE CONSTITUTIONALITY OF AN ADMINISTRATIVE \\ PRATICE BASED ON TRADITION
}

\author{
Leonardo Martins" \\ Diogo Caldas Leonardo Dantas*
}

\begin{abstract}
Resumo: A constitucionalidade da presença de crucifixos nas repartições públicas brasileiras ainda não foi adequadamente avaliada pela literatura jurídica e pelos tribunais. Partindo-se de uma análise da situação concreta e das decisões pertinentes, buscou-se encontrar o fundamento normativo de tal prática e da argumentação jurídica usada pelos órgãos estatais que avaliaram o caso e chancelaram a prática com fulcro meramente consuetudinário. Fez-se a análise em abstrato das normas constitucionais pertinentes da Constituição Federal (CF) para, então, proceder-se à análise da constitucionalidade da determinação administrativa da presença de crucifixos. Trata-se, em suma, de se responder, fundamentadamente, se e em que medida se está diante de uma intervenção estatal no direito fundamental à liberdade de crença, e se tal intervenção restaria justificada constitucionalmente, caso em que o art. $5^{\circ}$, VI, da Constituição Federal não teria sido violado. Conclui-se pela ausência de uma justificação constitucional e consequente verificação da violação do direito fundamental decorrente do mesmo art. $5^{\circ}$, VI.
\end{abstract}

Palavras-chave: Constituição Federal. Direitos fundamentais. Liberdade de crença. Crucifixos.

\begin{abstract}
The constitutionality of the presence of crucifixes in Brazilian public offices has not been adequately considered by the legal literature or by the courts. This research aimed to find the normative base of such practice as well as of the legal argument used by the state agencies that analyzed the case and approved the practice with merely a customary fulcrum. It does so from an analysis of the concrete situation and pertinent decisions. An abstract analysis of the relevant constitutional norms of the Federal Constitution of 1988 was performed, followed by a review of the constitutionality of the administrative provision of the presence of crucifixes. In short, we sought to give a reasoned answer whether and to what extent the state is intervening in the fundamental right of freedom of belief and if such intervention is constitutionally justified-in which case the art. $5^{\text {th }}, \mathrm{VI}$, of the Constitution would not have been violated. With this study, we found that there was a lack of constitutional justification for the presence of the crucifixes; consequently, we verified the violation of the fundamental right inscribed in the art. $5^{\text {th }}$, VI.
\end{abstract}

Keywords: Federal Constitution. Fundamental rights. Freedom of religion. Crucifixes.

\footnotetext{
" Pós-doutor pela Humboldt-Universität Zu Berlin, HUB, Alemanha; Doutor em Direito Constitucional pela Humboldt-Universität zu Berlin da Alemanha; Mestre em Jurisdição Constitucional pela Humboldt-Universität zu Berlin da Alemanha; Professor Associado I na Universidade Federal do Rio Grande do Norte; Campus Universitário Lagoa Nova, Lagoa Nova, Caixa Postal 1524, 59072-970, Natal, Rio Grande do Norte, Brasil; leonardomartins1@yahoo.de

"* Mestre em Direito pela Universidade Federal do Rio Grande do Norte; Pós-graduado em Direito Constitucional pela Universidade Federal do Rio Grande do Norte; Advogado; diogocld@hotmail.com

1 O artigo é resultado de pesquisas promovidas pelos autores do quadro institucional do Grupo de Pesquisa Constituição Federal e sua Concretização pela Justiça Constitucional (PGD e PPGD-UFRN). Os autores agradecem à MSc Carmen Vasconcelos por sua muito competente leitura crítica do manuscrito e valiosas observações, assim como às observações finais de um dos dois pareceristas ad hoc no sistema double peer review e à equipe de revisão editorial da EJLJ por seu muito competente trabalho.
} 


\section{Introdução}

No dia a dia e reiteradas vezes, certas práticas relevantes em face de direitos fundamentais individuais passam despercebidas. Mesmo quando notadas, seus reflexos jurídicos não são reparados por seus responsáveis, e suas consequências normativas não são devidamente aplicadas. Essa é a situação dos crucifixos presentes em repartições públicas do Estado brasileiro que, respaldados pela crença religiosa da maioria de sua população, não é questionada quanto à sua constitucionalidade. Contudo, tal questionamento já se justifica quando se traz à pauta uma possível violação da liberdade de crença do art. 5, VI, da Constituição Federal (CF). Como ocorre com qualquer direito fundamental, especialmente este pode implicar uma necessária imposição de decisão contramajoritária que é da competência do órgão ou dos órgãos responsáveis pelo controle normativo de constitucionalidade.

A par da (não) fundamentação da técnica questão jurídico-constitucional, o amadurecimento político do País e da consciência democrática de sua população tem levado à percepção e ao questionamento da prática aqui estudada. Assim, busca-se esclarecer a situação brasileira a partir de uma preocupação jurídico-metodológica. Trata-se de construir um parâmetro racional jurídico-constitucional para a solução da questão no Brasil com a interpretação não apenas da CF e de outras fontes normativas infraconstitucionais, como também das pertinentes decisões administrativas e judiciais.

O parâmetro constitucional específico é o direito fundamental à liberdade de crença, ainda não trazido com o devido rigor na discussão jurídica pátria. A questão que se coloca, por excelência, é saber se e de que maneira o Estado viola esse preceito fundamental. Para tanto, há de se verificar, primeiro, se tal intervenção, uma vez caracterizada, pode ser justificada a partir da aplicação proporcional de seus limites constitucionais, notadamente mediante uma metodologicamente correta aplicação do critério da proporcionalidade.

Poder-se-ia trazer à pauta também o parâmetro constitucional do art. 19, I, da CF, como, aliás, faz boa parte da literatura jurídica pátria especializada. Indubitavelmente, paira no contexto fático estudado, no mínimo, uma hipótese de violação desse dispositivo constitucional que positivou o princípio do Estado laico. Optou-se, em recorte metodológico e com vistas à observância das limitações de espaço editorial, por não se realizar um exame exaustivo em face desse parâmetro. De um lado, sabidamente, basta verificar-se a violação de um dispositivo constitucional para se fulminar o ato estatal que configura aqui o objeto do exame de constitucionalidade. Independentemente dos efeitos de sua declaração (plano da sanção), não existem leis ou atos do poder público em sentido lato que sejam mais ou menos inconstitucionais: um ato normativo em sentido lato (incluindo as normas concretizadas pela jurisdição) ou executório estatal é ou não compatível com o parâmetro constitucional supremo. Por outro lado, tem-se uma parcial concorrência normativa entre um princípio jurídico-objetivo e um direito fundamental que tem também, como todos os direitos fundamentais, uma dimensão jurídico-objetiva. Em se tratando de normas constitucionais de natureza e função distintas, em alguns casos, poderiam ser aplicadas conjuntamente para o efeito de fortalecerem o alcance da posição jurídico-subjetiva derivada do direito fundamental do art. 5, VI, da CF. Por fim, 
embora ambos os dispositivos cumpram a função de restringir negativamente a competência estatal, impondo-lhe limites, a opção pelo presente recorte metodológico enfatiza o status libertatis ou status negativus decorrente do art. $5^{\circ}$, VI, da CF, com sua consequente pretensão jurídico-subjetiva à "resistência" ou "defesa" contra intervenções estatais. A historiografia revela quão presente está a função de proteção de minoria política na tutela constitucional da liberdade de crença. Portanto, não se trata, em primeira linha, de se discutir a cogente neutralidade ético-religiosa do Estado, bem jurídico-constitucional protegido pelo princípio objetivo do Estado laico por excelência, mas da possível violação de um concreto direito fundamental de liberdade individual.

\section{Da percepção do problema sociopolítico e sua tradução jusfundamental}

A fixação de crucifixos em paredes é praxe em muitas repartições públicas brasileiras. Trata-se, sabidamente, de um símbolo da crença católico-cristã que é pendurado em paredes de secretarias, salas de audiência e gabinetes de autoridades públicas. Fundada mais na tradição do que em atos normativos, tal prática está presente até nos órgãos de cúpula do Estado brasileiro. ${ }^{2}$ Por exemplo, na sala do plenário do Supremo Tribunal Federal (STF), há um crucifixo na parede localizado às costas da cadeira do Presidente do Tribunal.

Apesar de recorrente, a prática foi questionada algumas vezes, com base nos parâmetros, sobretudo, da laicidade do Estado (art. 19, I, da CF) e do caráter taxativo dos símbolos da República (art. 13, $\mathbb{S} 1^{\circ}$, da CF). Como exemplo de combate à prática em apreço, mencionem-se alguns processos no Conselho Nacional de Justiça (CNJ). Nos pedidos de providência n. 1344, 1345, 1346 e 1362 julgados em 2007, o CNJ considerou que a exposição do símbolo religioso católico não viola a CF e não estabelece uma religião do Estado ou de seu servidor. Os crucifixos expostos nas repartições não somente estariam, segundo o CNJ, em consonância com a crença da maioria da população brasileira como também seriam um elemento da cultura do País. ${ }^{3}$ Em momento posterior, o CNJ voltou a se deparar, de maneira incidental, com a questão em análise. Em 2009, o então recém-nomeado Presidente do TJ/RJ determinou a retirada dos crucifixos que estavam espalhados pelo Órgão e a

\footnotetext{
2 A controvérsia acerca da "promoção" de uma religião pelo Estado mediante imposição de símbolo ou prática religiosa não é exclusiva do Brasil. Muitas Cortes já se debruçaram sobre o tema e chegaram a relevantes conclusões em seus respectivos contextos jurídicos. Nesse sentido, cf. o caso Kruzifix (BVerfGE 93, 1) do TCF alemão ou excertos traduzidos em Martins (2005, p. 366-377) e os casos Engel v. Vitale (370 U.S. 421 - 1962) e County of Allegheny v. ACLU (492 U.S. 573 - 1989) julgados pela Suprema Corte norte-americana e a análise de Nowak e Rotunda (2007, p. 790-791) dos métodos de decisão dessa Corte. A Corte Europeia de Direitos Humanos (CEDH) julgou, em 2011, um caso similar (Lautsi v. Italy) em que se requeria a retirada dos crucifixos das escolas públicas italianas, prática embasada naquele País nos decretos reais n. 965/1924 e n. 1.297/1928, que determinavam a presença de um crucifixo nas salas de aulas das instituições de ensino públicas. Na ocasião, a CEDH julgou improcedente o pedido por não ter sido verificada uma violação específica do direito europeu (art. 9 da Convenção Europeia de Direitos Humanos e art. $2^{\circ}$ do Protocolo n. 1 do mesmo documento), absolvendo o Estado italiano. A experiência amealhada pela jurisprudência de cortes estrangeiras é uma ferramenta comparativa que contribui para o debate interno e a solução de equiparáveis controvérsias. Por uma análise do papel da jurisprudência estrangeira, cf. Tavares (2012, p. 111-156).

3 A esse respeito, cf. Marmelstein (2013, p. 111); site do CNJ com as decisões: < http://www.cnj.jus.br/noticias/64462-uso-de-solos-religiosos-nfere-laicidade-do-estado > e <http://www.cnj.jus.br/noticias/64478-cnj-encerra-julgamento-sobre-solos-religiosos-no-poder-judicio]; notícia veiculada no site do Conjur: <http://www.conjur.com.br/2007-mai-29/uso_simbolo_nao_fere_carater_laico_estado_cnj>. Acesso em: 13 jan. 2016.
} 
desativação da capela. A questão chegou ao CNJ, que, no pedido de providências n. 1859 (BRASIL, 2009), determinou ao Presidente do TJ/RJ que submetesse a decisão monocrática em questão ao seu órgão especial, conforme norma de seu regimento interno. Do mesmo modo, o MP/SP, na Petição n. 48723/07 (BRASIL, 2007), a qual questionava a presença do símbolo religioso em questão na Câmara Municipal daquele Estado, seguindo a linha político-decisória do CNJ, também entendeu que não haveria violação do art. 19, I, da CF. A fixação desse objeto não resultaria na determinação de uma religião estatal. Por sua vez, o TJ/RS, em expediente administrativo, decidiu pela retirada dos crucifixos dos espaços de acesso públicos dos prédios do Poder Judiciário. Para fundamentar tal decisão, trouxeram-se os princípios da impessoalidade e da laicidade do Estado (BRASIL, 2012). ${ }^{4}$

Entre todas as decisões no mesmo sentido, destaca-se a do CNJ nos pedidos de providência n. 1344, 1345, 1346 e 1362 (BRASIL, 2007) por sua repercussão nacional. ${ }^{5}$ Em diversas passagens, o relator da decisão analisa a questão sob o prisma de um conflito entre o interesse público primário (proteção dos direitos individuais) e o interesse público secundário (vontade do órgão público na manifestação cultural). Segundo ele, estariam contrapostos o costume culturalmente estabelecido da fixação de símbolos religiosos, a liberdade de consciência e crença e a laicidade do Estado. Contudo, apesar da menção ao direito fundamental do art. $5^{\circ}$, VI-VIII, da CF, o parâmetro constitucional utilizado na decisão foi tão somente o art. 19, I, da CF, não havendo uma análise detida dos preceitos constitucionais que resguardam o direito fundamental à liberdade de consciência e crença. Ademais, o relator sustentou que a presença de um crucifixo nas salas de audiências de um tribunal não ofenderia o art. 19, I, CF. Pelo contrário, sua presença assegurá-lo-ia porque não teria o condão de ofender o interesse público primário. Assim, o relator da decisão do CNJ em tela parece entender que a liberdade de consciência e crença tenha uma dimensão positiva, de caráter prestacional. No Pedido de Controle Administrativo n. 1418 (BRASIL, 2016), foram reiteradas mediante decisão monocrática de maio de 2016 as razões da decisão paradigmática sobre o caráter cultural do crucifixo. Afirmou-se, sem nenhum argumento jurídico-dogmático, que a prática não representaria a constitucionalmente vedada (art. 19, I, da CF) mistura entre religião e Estado. Por fim, em sua decisão monocrática, o relator sustentou que não existiria na CF uma vedação expressa ao ato estatal de fixar crucifixos em repartições públicas.

Essa avaliação do caso a partir da dicotomia entre interesse público e interesse privado ou entre interesse público primário e interesse público secundário não pode ser feita nesses termos. Tendo em vista a fragmentação do interesse público, ${ }^{6}$ é comum o conflito entre esses interesses. Não há uma necessária contraposição entre interesse público e interesse privado, o mesmo valendo para a suposta contraposição entre interesse público primário e interesse público secundário. Mesmo que a argumentação do relator estivesse correta quanto à classificação dos interesses públicos no caso em apreço (a proteção dos direitos fundamentais como interesse público primário e a vontade do

\footnotetext{
4 Essa decisão foi reformada pelo CNJ no Pedido de Controle Administrativo n. 1418, a ser analisado a seguir.

5 Nesse sentido, cf. meios de comunicação que noticiaram a questão: <http://www.conjur.com.br/2007-mai-29/uso_simbolo_nao_fere_carater_laico_estado_cnj>; <http://g1.globo.com/Noticias/Brasil/0,MUL44120-5598,00.html>; <http://

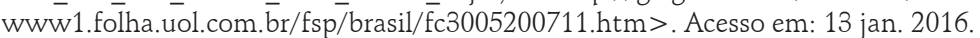

6 Cf. Justen Filho (2012, p. 116).
} 
órgão público na manifestação cultural como correspondente do interesse público secundário), sua conclusão estaria equivocada. Concretamente, o relator conclui pela prevalência da manifestação cultural pelos órgãos estatais em face da defesa dos direitos fundamentais. Todavia, segundo seu entendimento, não haveria um real conflito, pois o primeiro reforçaria e seria condizente com o segundo, não havendo que se falar em inconstitucionalidade. Nessa questão foi ignorada, primeiro, a possibilidade do exercício negativo do direito fundamental à liberdade de consciência e crença a ser mais bem estudado a seguir. Segundo, há um equívoco teórico, jurídico-dogmático e metodológico, que é submeter a tutela de direitos fundamentais individuais a supostos interesses públicos, cujos guardiões seriam os órgãos estatais. Pelo contrário, no que se refere à dimensão jurídico-subjetiva dos direitos fundamentais, os órgãos estatais figuram no polo passivo da relação juspublicista, ou seja, são os órgãos estatais os destinatários normativos, os entes vinculados e obrigados a um fazer, a um não fazer ou a um permitir. Por isso, a proteção aos direitos fundamentais pode implicar, no caso concreto, a prevalência de direitos individuais em face de interesses ditos "públicos". P Para tanto, basta a comprovação de uma intervenção estatal injustificada em direito fundamental individual, ainda que seu propósito supostamente seja a imposição do interesse público em face do privado. $\bigcirc$ princípio jus-administrativo da prevalência do interesse público encontra seus limites na dogmática dos direitos fundamentais, sob pena de se subverter o sentido normativo das suas normas definidoras, dotadas sabidamente de supremacia dentro do ordenamento jurídico nacional. Uma avaliação tão correta quanto precisa da relação jurídica em pauta é imprescindível para a satisfatória solução do problema, não se podendo aceitar aqui tais soluções fáceis e até levianas juridicamente. ${ }^{8,9}$

No mais, à exceção da hipótese do art. $5^{\circ}$, VII, da CF, a liberdade de crença do art. $5^{\circ}$, VI e VIII, conforme o teor de sua positivação, o contexto sistemático como liberdade individual e sua interpretação histórica que reforça seu caráter de direito de resistência (ou de defesa) é um direito fundamental individual de status libertatis ou status negativus. ${ }^{10}$ Tipicamente, sua violação ocorre por atuação comissiva estatal e não omissiva. Também, outros argumentos constantes da ora analisada decisão do CNJ são absolutamente infundados. Por exemplo, não há de se falar em "independência administrativa do Poder Judiciário" para a finalidade de com ela legitimar-se a ornamentação de edifícios do Poder Judiciário de acordo com critérios de seus servidores, incluindo, obviamente, os servidores magistrados. Tecnicamente, tal independência não tem como servir de propósito lícito constitucionalmente a justificar uma intervenção na liberdade de crença daqueles que não professam a crença católico-cristã. ${ }^{11} \mathrm{~A}$ independência administrativa do Poder Judiciário pode ser avocada

\footnotetext{
Cf. Justen Filho (2012, p. 116-118).

8 Nesse sentido, cf. Justen Filho (2012, p. 123, 127-129) e Freitas (2009, p. 58-59).

9 O debate acerca da prevalência do interesse público na literatura especializada brasileira muitas vezes pode induzir a erro, pois é capaz de fazer o aplicador do Direito sempre concluir em favor do interesse público. Alguns autores são expressos nesse sentido (MELLO, 2008, p. 96-99; DI PIETRO, 2014, p. 65-68; CARVALHO FILHO, 2004, p. 21). Esse entendimento deve ser visto com cuidados quando estiver em jogo a análise de medidas estatais em face dos direitos fundamentais. Com efeito, no âmbito constitucional, a ação estatal deve ser amparada por uma competência e sua potencial intervenção em um direito fundamental deve ser constitucionalmente justificada, o que pode levar ao afastamento do interesse público em face da prevalência de um direito fundamental individual.

10 Cf. Martins (2012, p. 355).

11 Para uma análise desse julgamento na literatura jurídica, cf. Novelino (2013, p. 512).
} 
somente para assegurar que o chamado terceiro poder bem desempenhe sua imprescindível função constitucional, não para satisfazer a quaisquer desideratos de seus membros, sejam esses desideratos fundados ou não em uma crença, seja ela qual for. De resto, a afirmação segundo a qual não existiria uma vedação constitucional expressa ao ato de fixar crucifixos não apenas não convence; ela está eivada de notória incompreensão a respeito da natureza jurídica de direitos fundamentais em geral e não somente da natureza do direito fundamental à liberdade de crença, assim como também da função da Constituição jurídica de um Estado. Em primeiro lugar, a outorga pelo constituinte do direito fundamental à liberdade de crença no art. $5^{\circ}$, VI, da CF, como direito público-subjetivo que é, traça limites à ação estatal nessa seara em prol do aspecto específico de liberdade e autodeterminação individuais. Direitos fundamentais são definidos por normas com teor necessária e intencionalmente mais lacônico e abstrato ou "lapidar", no sentido de ser econômico em palavras, ${ }^{12}$ ensejando necessário grande esforço hermêutico-interpretativo para a aferição de seu alcance concreto. Tem-se, na maior parte das normas definidoras de direitos fundamentais, uma intencionada abertura conceitual a novos reconhecimentos de carência de proteção específica de liberdades negativas. Assim, não surpreende a inexistência de uma vedação tão particular. Pelo contrário, essa vedação expressa causaria certo constrangimento hermenêutico em face de um texto constitucional que seria deveras exótico na comparação com congêneres de Estados constitucionais democráticos. Na dúvida, vale a presunção pela predominância da liberdade, ou seja, em prol da abertura do direito fundamental a comportamentos que devam ser, em princípio, livres da intervenção estatal. Em segundo lugar, o princípio da laicidade do Estado, estatuído pelo art. 19, I, da CF, também funciona, por seu caráter jurídico-objetivo e, com isso, independentemente de reinvindicação judicial de posições jurídico-subjetivas derivadas de normas definidoras de direitos fundamentais, como restrição - esta ao contrário do que acontece com direitos fundamentais, que foram outorgados todos com limites constitucionais - absoluta, a qualquer tipo de atuação do Poder Público que implique favorecimento de qualquer organização, liturgia ou culto religioso. Em suma, as vedações constitucionais específicas à atuação do Estado, precipuamente decorrentes de direitos fundamentais ou princípios jurídico-objetivos como o definido no art. 19, I, da CF, em regra, não são previstas expressamente no texto constitucional. A própria inclusão de determinado bem jurídico na CF funciona como limite; as restrições concretas são verificáveis após cuidadosa interpretação sistemática e análise do caso concreto, o que se propõe a fazer neste trabalho.

No caso do crucifixo presente no plenário do STF, em pedido de informações ${ }^{13}$ (Protocolo n. 283872) sobre o fundamento normativo para a sua fixação, sua Secretaria Judiciária respondeu, com base na supracitada decisão do CNJ, que a colocação de crucifixos em prédios do Poder Judiciário não viola a laicidade do Estado constitucionalmente estabelecida. Em um segundo pedido de infor-

$\overline{12}$ Diz-se, na literatura jurídico-constitucional alemã, que os direitos fundamentais foram propositalmente redigidos de maneira "lapidar", em uma referência metafórica às gravações insculpidas na pedra (nas lápides), daí seu teor necessariamente enxuto. Teor esse que é, inclusive, justamente em razão dessa sua característica, aberto a mutações constitucionais, desde que sejam enriquecedoras de seu conteúdo de liberdade. "Predominantemente eles [os direitos fundamentais] são formulados sintética e amplamente [...] e atuam de modo clausular genérico." (Cf. Pieroth et al., 2015, p. 1).

13 Cf. Anexo I. Disponível em: <https://pt.scribd.com/doc/301242345/Solicitacao-de-informacoes-sobre-crucifixo-STF>. Acesso em 29 fev. 2016. 
mações (Protocolo n. 283940), a Secretaria esclareceu que o símbolo é uma "obra cultural", sendo o painel de mármore de Athos Bulcão e o crucifixo de Alfredo Ceschiatti. ${ }^{14}$ Não existiria nenhuma norma positiva que embasasse a fixação do crucifixo na Sala do Plenário. O crucifixo estaria sujeito ao regime dos bens móveis regulamentado pela Instrução Normativa n. 163, de 21 de outubro de 2013. Nesse sentido, o art. $4^{\circ}$ da Instrução Normativa n. 163/2013 determina que os bens patrimoniais do STF somente podem ser destinados às unidades do Tribunal com o respectivo Termo de Responsabilidade emitido pela Seção de Controle do Patrimônio e assinado pelo agente responsável, qual seja, o chefe da Seção de Segurança de Instalações, em conjunto com a Secretaria de Documentação do STF, por causa do seu enquadramento como patrimônio histórico. ${ }^{15}$ Tais informações, prestadas pela Secretaria Judiciária do STF, acentuam dois aspectos do problema em tela. Primeiro, o papel exercido pela suprarreferida decisão do CNJ usada como justificativa para a medida controversa; segundo, a classificação dos crucifixos como bem cultural e patrimônio histórico.

Esses exemplos implicam um primeiro indício de que não se chegou a um consenso sobre a celeuma política, e os crucifixos continuam espalhados por repartições públicas as mais variadas. Entretanto, apesar de pouco discutido, muitas vezes falta ao debate sobre o tema a necessária perspectiva jusfundamental: além de se tratar de uma possível violação do mandamento constitucional de laicidade do Estado, também há uma potencial violação do direito fundamental à liberdade de consciência e crença dos indivíduos que, em suas tratativas com o Poder Público, deparam-se com o símbolo de uma religião específica. Em tal insuficiência, incorre até mesmo a citada decisão do TJ/RS, que em sede de conclusão (parte dispositiva do acórdão) é acertada, mas que, em sede de fundamentação, trouxe o correto exame com pauta no direito fundamental à liberdade de crença de maneira assaz marginal.

A discussão carece, destarte, de um exame jusfundamental que ora se propõe.

\section{Do delineamento jurídico-dogmático abstrato do direito fundamental à liberdade de consciência e crença}

Como se sabe, a ordem jurídica suprema do Estado democrático e constitucional de direito consolidada pela CF vincula toda autoridade estatal por ela formal e materialmente constituída. A CF assegura certas posições jurídico-subjetivas "fundamentais" por meio de sua consagração em seu texto (fundamentalidade formal) e de sua elevação à hierarquia de direitos fundamentais, considerados pela sociedade como os mais caros e imprescindíveis aos cidadãos. ${ }^{16}$

A religiosidade de um indivíduo e a possibilidade de ter ou não uma religião, e de exercê-la livremente, enquadram-se como elementos configuradores de um direito fundamental pelo menos desde o constitucionalismo de fins do séc. XVIII, estando presente nos primeiros documentos que

14 Cf. Anexo II. Disponível em: <https://pt.scribd.com/doc/301242345/Solicitacao-de-informacoes-sobre-crucifixo-STF>. Acesso em 29 fev. 2016.

15 Cf. Anexo III. Disponível em: <https://pt.scribd.com/doc/301242345/Solicitacao-de-informacoes-sobre-crucifixo-STF>. Acesso em 29 fev. 2016.

16 Para um estudo da relação entre Estado e religião, cf. Miranda (2000, p. 405-406). 
inicialmente ${ }^{17}$ o garantiram, como a Declaração dos Direitos do Homem e do Cidadão (1789) ${ }^{18}$ e o Bill of Rights da Constituição norte-americana (1789). ${ }^{19}$

A CF, como não poderia deixar de ser, não é exceção. Outorga o direito da liberdade de crença em vários dispositivos, limitando todos os poderes constituídos em face dela. Detidamente analisados devem ser aqui o art. $5^{\circ}$, VI, e o art. 19, I, da CF.

\section{1 Área de proteção do artigo 5०, VI, da Constituiç̧ão Federal}

A norma do art. $5^{\circ}$, VI, da CF positiva um direito de status negativus ${ }^{20}$ que assegura um direito de resistência (ou de defesa) ${ }^{21}$ em face do Estado. Ao proteger a inviolabilidade da liberdade de consciência e crença, estipula uma competência negativa ${ }^{22}$ à atuação estatal e uma esfera, em princípio, inacessível à sua ingerência.

Tanto o direito fundamental à liberdade de consciência quanto o direito fundamental à liberdade de crença são abarcados pela norma constitucional em tela. A distinta menção à consciência e à crença fora também amparada nas anteriores constituições brasileiras. ${ }^{23} \mathrm{~A}$ área de proteção ${ }^{24} \mathrm{da}$ primeira abrange a autodeterminação do indivíduo ao estabelecimento de uma norma moral ou ética subjetiva adotada para si vinculantemente. Essa autoimposição norteia a ação do titular segundo a sua adequação ou não àquela segundo os critérios do "bom", "justo", "correto"; e seus antônimos, ou quaisquer outros similares qualificativos. ${ }^{25}$ Assim, o direito fundamental em questão apresenta-se

\footnotetext{
17 Por um estudo, e com posições distintas, da origem dos direitos fundamentais, os elementos necessários para tanto e sua evolução histórica, cf. Dimoulis e Martins (2014, p. 10-37), Sarlet, Marinoni e Mitidiero (2012, p. 251-257), Marmelstein (2012, p. 27-57) e Canotilho (2000, p. 377-388).

18 "Art. $10 .^{\circ}$ Ninguém pode ser molestado por suas opiniões, incluindo opiniões religiosas, desde que sua manifestação não perturbe a ordem pública estabelecida pela lei." Original disponível em: <http://www.conseil-constitutionnel.fr/conseil-constitutionnel/root/bank_mm/anglais/cst2.pdf>. Acesso em: 13 jan. 2016.

19 "Primeira Emenda: O Congresso não editará nenhuma lei estabelecendo uma religião, ou proibindo o seu livre exercício; ou limitando a liberdade de expressão, ou de imprensa; ou do direito das pessoas livremente sereunirem, e de petição ao Governo para reparação de injustiças." Original disponível em: <http://www.senate.gov/civics/constitution_item/constitution. htm>. Acesso em: 13 jan. 2016.

20 Pelo conceito de direito de status negativus, cf. Dimoulis e Martins (2014, p. 49-51) e Pieroth e Schlink (2012, p. 62-63). Por uma crítica à teoria de Jellinek, que trata dos status dos direitos, cf. Alexy (2008, p. 254-255).

21 Categoria de direitos fundamentais chamada de "direitos de defesa" pela corrente majoritária que recepcionou o conceito germânico "Abwehrrecht". Nesse sentido, por todos cf. Mendes e Branco (2011, p. 178). Pela opção aqui seguida, e com boas razões, da tradução "direito de resistência" em vez de "direito de defesa", cf. Dimoulis e Martins (2014, p. 51 s.).

22 Os direitos fundamentais como competência negativa estatal são uma das manifestações da dimensão objetiva daqueles cuja "[...] percepção independe de seus titulares, vale dizer, dos sujeitos de direito. Os direitos fundamentais possuiriam também uma dimensão objetiva que ofereceria critérios de controle da ação estatal. Esses critérios de controle deveriam ser aplicados independentemente de possíveis intervenções e violações de direitos fundamentais de determinadas pessoas e da consequente reclamação por seu titular." (DIMOULIS; MARTINS, 2014, p. 111). Para uma análise das dimensões dos direitos fundamentais, cf. Dimoulis e Martins (2014, p. 109-122), Pieroth e Schlink (2012, p. 67-79), Sarlet, Marinoni e Mitidiero (2012, p. 295-299) e Sarlet (2010, p. 141-207).

23 Cf., por exemplo, a análise do correspondente na Constituição de 1946 por Miranda (1947, p. 237-238).

24 Pelo conceito e esclarecimentos acerca da área de proteção dos direitos fundamentais, com formas diferentes de tratamento, cf. Dimoulis e Martins (2014, p. 129-131), Pieroth e Schlink (2012, p. 115-118), Silva (2011, p. 72-73) e Alexy (2008, p. 302-307).

25 Cf. Martins (2012, p. 357). A esse respeito, Pieroth e Schlink (2012, p. 252) afirmam que avaliações segundo "bonito e feio" ou "verdadeiro e falso" não estariam incluídas na área de proteção em tela, porque escapariam aos elementos da "atitude moral" e "vinculante".
} 
como mais amplo do que a liberdade de crença, ${ }^{26}$ uma vez que, ao contrário desta, não exige uma relação com opções religiosas. ${ }^{27}$

Para efeitos do presente estudo relevante é, todavia, apenas a liberdade de crença. ${ }^{28}$ Sua área de proteção engloba a faculdade de ter, propor, praticar e expressar uma crença. É irrelevante se a fé professada é considerada de grande importância na sociedade ou se ostenta uma extensa lista de seguidores. ${ }^{29}$ Resguardam-se, assim, igrejas pequenas e novos cultos, além de crenças estranhas às, historicamente, mais influentes religiões no País. Necessária é, entretanto, uma aparência externa de religião ${ }^{30}$ e de comunidade religiosa, além do conteúdo espiritual da congregação. ${ }^{31}$

$\mathrm{O}$ alcance do direito fundamental em questão estende-se tanto sobre o seu exercício positivo quanto sobre o negativo. ${ }^{32}$ Protege-se a autodeterminação do indivíduo e a possibilidade de ter e escolher uma crença que mais bem se adeque aos seus valores e convicções ou que, então, os engendre ou os promova. Trata-se do direito de pensar de acordo com a própria crença e, reflexamente, de não se ver instado pelo Estado a não pensar em consonância com seus preceitos vinculantes. Além dessa defesa de foro íntimo, resguarda-se a projeção "externa" ao titular do direito fundamental, consubstanciada em sua manifestação. Logo, preserva-se tanto o "manifestar" uma fé como o "agir" segundo ela. ${ }^{33}$ A participação em atos litúrgicos, cultos e outros tipos de manifestações da religião encontram-se albergados pelo direito fundamental. Igualmente, garante-se a atuação segundo a religião. Entre outras, ações como o jejum realizado pelo católico na quaresma e o uso do véu por mulheres mulçumanas são abrangidas pelo art. $5^{\circ}$, VI, da CF. Consequentemente, o Estado carrega o ônus de justificar eventuais intervenções nas esferas subjetivas descritas.

Também se protege a organização religiosa, mediante a faculdade de vários titulares do direito fundamental, de formar e estabelecer regras internas para uma instituição religiosa. Aqui se tem um conteúdo semelhante ao da liberdade de associação, hipótese em que se verifica uma concorrência entre direitos fundamentais. ${ }^{34} \mathrm{O}$ ente religioso tem, nesse sentido, um poder de normatização referente à estrutura interna da organização religiosa. Protegida é, destarte, a configuração de cultos,

\footnotetext{
26 Nesse sentido, cf. Weingartner Neto (2007, p. 79 e ss.). Miranda (2000, p. 416) também faz essa distinção afirmando que a liberdade religiosa também tem uma dimensão social e institucional, que não existiriam, segundo ele, na liberdade de consciência. Em sentido contrário à generalidade do direito fundamental à consciência em relação à liberdade religiosa, cf. Hesse (1998, p. 299-300).

27 Cf. Sarlet, Marinoni e Mitidiero (2012, p. 463).

28 A análise ficará restrita à liberdade religiosa, mas parte das considerações é aplicável à liberdade de consciência. $\bigcirc$ estudo superficial foi aqui relevante para demonstrar que há distinção entre os dois direitos fundamentais consagrados no art. $5^{\circ}$, VI, da CF, o que resulta em uma melhor delimitação da área de proteção da liberdade de crença.

29 Cf. Pieroth e Schlink (2012, p. 246).

30 Noronha (2015, p. 93) defende que um conceito de religião estaria ligado a um sistema de crenças que envolvem um ser divino, a convicção de uma vida após a morte, um texto sagrado, rituais e orações.

31 Cf. Pieroth e Schlink (2012, p. 246-247).

32 Acerca do exercício positivo e negativo dos direitos fundamentais, cf. Dimoulis e Martins (2014, p. 131-134).

33 Pieroth e Schlink (2012, p. 245) abordam esse direito segundo quatro exercícios positivos básicos: "possuir", "formar", "manifestar" uma religiosidade e "agir" segundo ela. Na literatura especializada brasileira, Bastos e Martins (1989, p. 48) e Miranda (1947, p. 236-238) avaliam o direito fundamental em questão sob variados prismas.

34 Contudo, nesse aspecto, a liberdade de crença é lex especialis, pois enriquece as formas de exercício da liberdade de associação com mais um aspecto específico diferenciador. Assim, a aparente concorrência pode ser resolvida com a aplicação exclusiva e solitária da liberdade de crença. A esse respeito, cf. Dimoulis e Martins (2014, p. 163-167).
} 
liturgias, cerimônias, símbolos e demais minúcias. ${ }^{35}$ Igualmente, protegidos são os meios de arrecadação de valores para a subsistência da pessoa jurídica. ${ }^{36,37}$

Quanto ao exercício negativo, aspecto precípuo em face da finalidade de se avaliar a constitucionalidade da prática de afixarem-se crucifixos, objeto do presente exame, resguarda-se o direito a não ter crença, precisamente: a não ser obrigado a participar, ativa ou passivamente, de nenhum elemento doutrinário de qualquer crença ou alguma em especial. A proteção do exercício negativo de qualquer direito fundamental corresponde a uma das principais características dos direitos fundamentais, já que não se trata de deveres fundamentais. $O$ indivíduo tem o livre-arbítrio de fazer uso - ou não - do direito assegurado pela CF. ${ }^{38}$ Assim, a CF garante que o indivíduo não seja obrigado a se sujeitar a nenhum culto ou cerimônia de uma religião, em cujos ditames não acredite. Nesse contexto, insere-se a faculdade do titular do direito fundamental em tela de não reconhecer valor algum nos atos litúrgicos e símbolos religiosos. No caso em tela, é um exercício típico de tal faculdade "negativa" não ser "faticamente" exposto o titular a quaisquer símbolos religiosos a partir de medidas atribuíveis aos destinatários normativos que são todos órgãos estatais pertinentes aos três poderes constituídos. Reflexamente, constata-se nessa exposição provocada pelo Estado uma intervenção estatal no aspecto negativo de liberdade em pauta, carecedora de uma justificação constitucional. ${ }^{39}$

A justificação constitucional do verificado modo de intervenção estatal é em tese possível, desde que presentes duas condições. A primeira condição é a presença de um limite constitucional ao direito fundamental em tese violado, o que será objeto da próxima subseção. A segunda condição é a observância do critério (princípio) da proporcionalidade que deve ser verificada junto à imposição concreta do aludido limite constitucional, assunto apresentado na seção 3.

\subsection{Limites constitucionais à liberdade de consciência e crença}

O constituinte brasileiro previu, como o fazem muitos constituintes no contexto das democracias ocidentais, uma série de prováveis conflitos entre direitos fundamentais ou entre eles e outro preceito constitucional. Esse é o motivo, por excelência, de se estabelecerem, nos textos constitucionais, limites a direitos fundamentais, outorgando ao Poder Legislativo, mesmo na qualidade de poder constituído que é, uma competência discricionária para restringi-los. O legislador tenta, com o uso dessa competência discricionária, já ao nível normativo-abstrato, harmonizar os direitos fundamentais entre si e em face de eventuais outros bens jurídicos com status normativo

\footnotetext{
$\overline{35}$ No mesmo sentido, cf. Santos Júnior (2010, p. 40).

36 Cf. Martins (2012, p. 358-359).

37 Aqui há a conjugação do art. 150, VI, "b" c.c. e art. 150, \4 $4^{\circ}$, da CF.

38 Cf. Dimoulis e Martins (2012, p. 131-132).

39 Bastos e Meyer-Plug (2011, p. 408) condicionam as condutas albergadas ao respeito dos princípios da boa-fé pelos promotores dos cultos e a exclusão de qualquer prática incompatível com o ordenamento jurídico brasileiro. Em que medida, com pauta nessas opiniões, o caráter supremo de normas constitucionais como a do art. $5^{\circ}$, VI, da CF em face do direito infraconstitucional e o vínculo do poder constituído legislativo ordinário àquele possam ser observados não resta claro. Por sua vez, Silva (2009, p. 249-250) argumenta que a CF afastou a necessidade de a religião ter de respeitar a ordem pública e os bons costumes.
} 
constitucional, os quais, concretamente, podem colidir. Entre os limites aos direitos fundamentais, ${ }^{40}$ destaca-se a reserva legal, que pode ser classificada nas categorias "simples" ou "qualificada". Reservas legais da primeira categoria são comumente previstas em textos constitucionais por expressões como "na forma da lei" ou "nos termos da lei". Por sua vez, as reservas qualificadas preestabelecem ao legislador ordinário algum propósito e/ou meio legítimo de se chegar a ele, reduzindo a discricionariedade legislativa, que é mais ampla no caso das reservas legais simples. ${ }^{41}$ Essas previsões das reservas qualificadas ou ausência delas nas reservas simples deverão ser observadas na aplicação do critério da proporcionalidade como forma de se justificar uma antes verificada intervenção estatal no direito fundamental em tela. Portanto, antes de se aplicar os subcritérios relacionais da adequação e da necessidade, há de se verificar a idoneidade das grandezas em si a serem relacionadas, que são o meio de intervenção e o seu propósito.

No caso da liberdade de crença, foram aparentemente estabelecidos pelo constituinte dois limites constitucionais. Primeiro, trata-se de uma reserva legal simples à proteção aos locais de culto e suas liturgias, prevista na parte final do art. 5', VI, da CF ("na forma da lei"). Segundo, o art. 50, VIII in fine, da CF, prevê a escusa de consciência, que possibilita ao particular não realizar uma obrigação a todos imposta, mediante a realização de prestação alternativa. Como a principal forma de violar a liberdade de consciência e crença é justamente pela imposição de deveres gerais de acordo com uma posição político-ideológica preponderante, mas contrária a alguma fé, a previsão de uma prestação alternativa em primeira linha visa a resguardar o direito fundamental em questão. Todavia, o indivíduo somente poderá ser obrigado à prestação alternativa caso ela tenha sido configurada infraconstitucionalmente pelo legislador ordinário e esteja de acordo com o direito fundamental da liberdade religiosa, i.e., cuja imposição normativa e concreta reste constitucionalmente justificada. Trata-se de exame a ser aplicado à conformação infraconstitucional feita pelo legislador.

Poder-se-ia ter, no caso em tela, um exemplo de mandado legislativo para conformação de um direito fundamental de marca prestacional, no sentido de que a previsão legal da prestação alternativa seria um aspecto da área de proteção e não do seu limite. A análise das possíveis consequências dessa previsão desautoriza, todavia, essa interpretação. Trata-se, pelo contrário, de uma reserva legal qualificada em razão da predeterminação de seu propósito, que corresponde a um limite constitucional ao direito fundamental derivado do art. $5^{\circ}$, VI e VIII, os quais, conjuntamente, representam a positivação do direito fundamental de status negativus, ao contrário do previsto no art. $5^{\circ}$, VII, que consagrou um direito prestacional (de status positivus). Para a recusa de prestação do serviço militar ou de outros semelhantes deveres fundamentais por motivo de consciência ou crença, o constituinte estabeleceu a possibilidade de o legislador prever uma prestação alternativa com o propósito de distribuir os ônus cívicos de maneira minimamente equitativa. Somente a não previsão constitucional de obrigação alguma a ser infraconstitucionalmente criada pelo legislador

\footnotetext{
40 Por uma abordagem dos limites constitucionais, cf. Dimoulis e Martins (2014, p. 144-159).

41 Por exemplo, vide o art. $5^{\circ}$, XII, da CF que garante o sigilo de correspondência, comunicações telegráficas, de dados e das comunicações telefônicas, mas que autoriza que as últimas sejam limitadas por decisão judicial (meio) e para fins de investigação criminal ou instrução processual penal (finalidade). A esse respeito, cf. Dimoulis e Martins (2014, p. 147).
} 
implicaria descaracterizar a menção à lei do art. 50, VIII, da CF como limite à outorga do art. 5, VI e VIII, da CF. Ainda que a prestação alternativa não tenha o condão de significar um ônus imposto especificamente às condutas abrangidas, no caso, pela liberdade de consciência, há um ônus reflexo sofrido pelo titular do direito fundamental provocado, na origem, pelo exercício em tese de sua consciência ou crença contrárias à "obrigação legal a todos imposta". A configuração concreta da reserva qualificada pelo legislador variará em termos de intensidade interventiva, mas em regra implicará intervenção carecedora de justificação. Quando a prestação alternativa ao serviço militar resultar, como no Brasil, em serviço alternativo dentro do âmbito das Forças Armadas que não a lida com armas, a percepção de competência pelo legislador dependerá da abrangência concreta da área de proteção do art. $5^{\circ}$, VI e VIII, da CF. Ela seria mera configuração de uma garantia constitucional apenas se não se considerar a recusa em prestar serviço não militar, mas prestado no âmbito das Forças Armadas, como um comportamento individual abrangido pela área de proteção. Como a liberdade é de consciência ou crença, fenômenos típicos da imperatividade ético-moral, de foro íntimo, portanto, a presente classificação como limite, de um lado, ou mera configuração de conteúdo, não censurável constitucionalmente, de outro, com fulcro no parâmetro do art. $5^{\circ}$, VI, da CF, dependerá da percepção pelo titular do direito fundamental e não de uma avaliação axiologicamente orientada (e comprometida) por órgãos estatais. Em outras palavras: a autodeterminada compreensão do alcance do próprio direito fundamental por seu titular será sempre o fator determinante a diferenciar o caráter interventivo ou não de atos administrativos, decisões judiciais ou atos normativos lato sensu. $\mathrm{Na}$ dúvida, afirma-se, in dubio pro libertate, o caráter interventivo, mesmo porque a intervenção não implica automaticamente a violação do direito fundamental intervindo, uma vez que ao cabo da interpretação dos limites constitucionais aplicados poderá restar justificada constitucionalmente.

No mais, outros limites à liberdade de crença, que escapem ao fenômeno específico descrito, recaindo tão somente sobre o inc. VI do art. $5^{\circ}$ da CF, somente poderão decorrer do direito constitucional de colisão, ${ }^{42}$ devendo as intervenções nele fundadas observar o critério da proporcionalidade.

Notoriamente, não se trata, no caso em tela, de limite derivado da descrita reserva legal qualificada. Logo, a presença de crucifixos em repartições públicas somente pode ser, em tese, justificada com fulcro em limite decorrente do sistema constitucional em sentido estrito, i.e., em um bem jurídico tutelado pela própria CF (direito constitucional colidente).

\section{Controle de constitucionalidade da exposição de crucifixos em repartições públicas}

Trata-se, na presente seção, de serem aplicados os critérios abstratos anteriormente descritos, a fim de se verificar a presença de uma intervenção justificada ou não na área de proteção do art. $5^{\circ}$, VI, da CF, concluindo-se pela constitucionalidade ou não da medida estatal em comento.

\footnotetext{
$\overline{42}$ A esse respeito, Dimoulis e Martins (2014, p. 156 e ss.).
} 


\subsection{Das intensidades de intervenção na área de proteção do artigo 5º, $\mathrm{VI}$, da Constituição Federal}

A determinação ou prática de fixação de um crucifixo em repartições públicas determinadas ou de responsabilidade de órgão público, aparentemente, não representa uma intervenção direta no exercício positivo do direito fundamental em questão, pois não restringe nenhuma das condutas básicas de "pensar" conforme, "ter", "manifestar", "agir" ou "criar" uma religião.

À pauta vem, em primeiro lugar, uma possível violação do exercício negativo da liberdade de crença. A medida ou prática atribuída a órgão público de fixar crucifixos nas repartições submete o indivíduo, que lida diária ou mesmo pontualmente com o Estado, a uma eventualmente não desejada contraposição a símbolo de religião da qual não seja membro. Tal imposição apresenta-se como inevitável, já que o particular que precisa manter relações com o Poder Público não tem alternativa se não fazê-lo sob a presença do símbolo religioso em tela. Esse constrangimento pode ser mais ou menos prolongado ou repetitivo, dependendo da natureza dos negócios a serem tratados na repartição pública, implicando diferentes intensidades interventivas. Esse elemento do tempo da exposição ao crucifixo também foi considerado pelo TCF alemão ${ }^{43}$ em um caso no qual se avaliou uma norma estadual que determinava a afixação de crucifixos em escolas públicas não confessionais. Embora a hipótese analisada pela Corte constitucional alemã seja de uma intervenção mais intensa, porque mais prolongada ${ }^{44}$ por ocorrer no âmbito escolar, valem aqui mutatis mutandis as mesmas considerações. Se o indivíduo seguir uma crença que tenha como um dos seus mandamentos a proibição de adorar o seu Deus por meio de figuras ou esculturas, como ocorre no caso de algumas correntes cristãs (protestantes) e judaicas, a intervenção na área de proteção do direito fundamental à liberdade de crença será mais intensa.

Pode-se, no aludido caso de a contraposição com o símbolo religioso significar também além de uma intervenção em exercício negativo - a violação de um preceito religioso específico seguido por aquele que é submetido à inevitável visão, constatar, inclusive, uma intervenção no exercício positivo do direito fundamental, pois a ostentação da escultura litúrgica tem o condão de afetar o seu livre "pensar" de acordo com seus preceitos, autodeterminadamente considerados estritamente vinculantes. $^{45}$

\subsection{Da justificação da imposição do limite constitucional derivado de direito constitucional colidente}

O pressuposto da justificação constitucional da imposição concreta de um limite constitucional a direito fundamental é que ela observe o critério da proporcionalidade. Como verificado, tra-

\footnotetext{
$\overline{43}$ Cf. BVerfGE 93, 1 (Kruzifix-Urteil). Principais excertos da decisão e instrutivas sínteses da matéria decidida e anotações podem ser encontradas em Martins (2005, p. 366-377).

44 Confronto inevitável, diário e por várias horas sofrido pelas crianças.

45 Cf. Martins (2012, p. 356-358).
} 
ta-se de um direito constitucional colidente e não da hipótese de reserva legal simples ou qualificada. O bem jurídico que representa o limite tem de, portanto, derivar diretamente da CF.

Trata-se de um ponto muito problemático do presente exame, pois, como visto, não há nenhum tipo de ato normativo que embase a medida estatal em tela, tratando-se de algo fundado na tradição e nos costumes. Já há um problema de legalidade em sentido estrito que não poderá ser mais bem analisado nos limites da presente exposição. ${ }^{46}$ Também se trata, nesse ponto, de um elemento muito distinto daqueles presentes no citado caso decidido pelo TCF alemão. Lá o objeto de controle normativo de constitucionalidade era uma lei ordinária promulgada pelo órgão competente - Poder Legislativo - que prescrevera a presença de crucifixos nas salas de aula com formas e medidas predeterminadas.

Ocorre que, nos países de sistema jurídico de civil law, somente a lei-em sentido amplo -é considerada fonte imediata do direito. Por consequência, somente na hipótese de um comando legal geral e abstrato para o uso dos costumes é que se poderia aceitar sua aplicação. No caso do ordenamento jurídico brasileiro, as previsões de uso das normas consuetudinárias são poucas, a citar, o art. $4^{\circ}$ da Lei n. 4.657/1947 (Lei de Introdução às Normas do Direito Brasileiro - LINDB), que autoriza uma incidência subsidiária em relação àquelas, ${ }^{47}$ na hipótese de omissão ou obscuridade da lei. Resta saber se pode o Estado, para além da suspeita de ilegalidade, restringir um direito fundamental por meio de uma prática destituída de amparo legal, apenas tolerada tradicionalmente.

$\mathrm{O}$ art. $5^{\circ}$, II, da CF, estabelece que somente por meio de lei os particulares podem ser obrigados a fazer ou deixar de fazer algo. Trata-se da reserva de Parlamento que funciona como uma imposição constitucional a ser observada para a limitação dos direitos fundamentais. ${ }^{48}$ Como não se está diante de uma lei em sentido formal que fosse promulgada por órgão competente, e, mediante observância do processo legislativo estabelecido pela CF em seu art. 59 e seguintes, o requisito jusfundamental da imposição por lei de limites ao direito fundamental em apreço, pelo menos em seus aspectos essenciais, não foi observado. Tratar-se-ia da correta e necessária aplicação da chamada "teoria da essencialidade", ${ }^{49}$ segundo a qual pode ser delegada ao legislador administrativo infralegal a regulamentação tão somente dos detalhes, mas não dos aludidos aspectos essenciais da intervenção legislativa configuradora do limite constitucional ao direito fundamental (atualização da reserva legal para a reserva parlamentar). No mais, ter-se-ia de trazer à tela o princípio da legalidade do art. 37 da CF, que impõe, cogentemente, a submissão da Administração Pública à lei, somente podendo atuar quando expressamente por ela autorizada. ${ }^{50}$

Questiona-se, de resto, se estaria presente a hipótese do art. $4^{\circ}$ da LINDB. A determinação de se trazer crucifixos a paredes de repartições públicas poderia ser legitimada segundo a argumentação exposta pelo CNJ por sua suposta natureza de "bem cultural", em que se enquadram costumes,

\footnotetext{
46 A esse respeito, cf. Dimoulis e Martins (2014, p. 154 e ss.).

47 Nesse sentido, ver esclarecimentos de Dimoulis (2011, p. 183-187).

48 Pieroth e Schlink (2012, p. 132-137) demonstram a evolução da reserva de lei, passando pela reserva do parlamento, até a reserva de lei proporcional. Sobre sua recepção brasileira, cf. Dimoulis e Martins (2014, p. 16-20; 176 e ss.).

49 Vide a respeito: Dimoulis e Martins (2014, p. 162-163).

50 Cf. Mello (2008, p. 105).
} 
tradições e religiões. ${ }^{51}$ Assim, com base tanto no dispositivo mencionado quanto no art. 126 do CPC/1973, o magistrado deveria decidir em prol do costume. Em sede de conclusão, o juiz poderia regular limites que o legislador decidira não exercer se fundamentados por um costume.

Adotando-se tal entendimento, abre-se a possibilidade de se restringir um preceito constitucional a partir de uma norma consuetudinária. Isso implicaria subjugar a Constituição a uma fonte do direito que é reconhecidamente subsidiária. Questionável é também a mera classificação do fato de trazer crucifixos às paredes de repartições públicas como costume no sentido da legislação de introdução ao direito privado. A compreensão do costume concreto em tela, como fonte de direito, é equivocada sob qualquer prisma de observação: quando um órgão estatal ornamenta edifícios públicos que os alberga, sem nenhum amparo legal, precipuamente quando o ornamento é, em verdade, um símbolo religioso, age com puro arbítrio e seguindo a lógica do patrimonialismo estatal brasileiro da não separação entre os espaços públicos-estatais e os privados. ${ }^{52}$

Somente essa evidência já seria suficiente para determinar a inconstitucionalidade da prática ora questionada. Entretanto, para um estudo mais profundo, há de se avançar na investigação da constitucionalidade para saber se, uma vez desconsiderado o vício apontado, esse ato poderia ser considerado compatível com a CF. Trata-se de aplicar, nesse ponto do exame, o argumento concessivo. Diante da ausência de fundamentos claros para a fixação dos crucifixos, toma-se como objeto do controle normativo de constitucionalidade a norma concreta implícita na decisão do CNJ, que considerou que o catolicismo e seus símbolos representariam tão somente traço cultural da sociedade brasileira.

Como visto, o CNJ procurou embasar sua decisão, não apenas no aspecto cultural, mas também no suposto fato de que o catolicismo seja a crença da maioria da população brasileira. ${ }^{53}$ Ainda que seja procedente essa informação, a CF protege pelo parâmetro constitucional ora aplicado as minorias, sobretudo as minorias religiosas, em face de assim chamados "poderes sociais" exercidos, por exemplo, por religiões numericamente dominantes. Embora essa função da constitucionalidade de proteger as minorias tenha sido distorcida em alguns momentos históricos, ${ }^{54}$ o primeiro objetivo político, transmutado em forma jurídica, continua sendo, antes de tudo, justamente essa proteção das minorias políticas. Portanto, o princípio majoritário, embora importante para a democracia por ser uma de suas principais formas de expressão, não supera o imperativo supracitado.

Questionável é saber em que medida aquela, pelo CNJ, alegada cultura, especificamente o símbolo da cultura ocidental enxergado no crucifixo, poderia representar um direito constitucional colidente e, como tal, um limite constitucional à liberdade negativa (ou, em parte, positiva) de crença. A proteção e a promoção da cultura pelo Estado encontra respaldo constitucional nos art. 215

\footnotetext{
51 Nesse sentido, cf. Tylor (1883, p. 1), Keesing (1972a, p. 49), Herskovits (1963a, p. 33), Eagleton (2005, p. 54-55) e Marconi e Presotto (1989, p. 41-44).

52 A respeito do patrimonialismo no Brasil e suas origens, cf. Holanda (1995, p. 145-146) e Faoro (1984, p. 8).

53 O Censo 2010 constatou que no Brasil havia cerca de 123 milhões de indivíduos que se declararam católicos. Nesse sentido, cf. o site do Censo 2010: <http://censo2010.ibge.gov.br/>. Acesso em: 13 jan. 2016.

54 A eficácia vinculante dos direitos fundamentais perante o Poder Legislativo era inexistente quando os direitos fundamentais eram entendidos como simples "reservas de lei". Nesse sentido, cf. Dimoulis e Martins (2014, p. 16-20) e Pieroth e Schlink (2012, p. 132 e ss.).
} 
e seguintes da CF. Para se verificar a presença de tal bem jurídico constitucional que serviria como limite que formalmente justificaria a verificada intervenção na liberdade de crença, é preciso determinar se a fixação de crucifixos em prédios públicos representa um caso de "proteção e promoção da cultura".

\subsection{0 critério da proporcionalidade como limite do limite}

O limite da promoção da cultura há de ser aplicado, portanto, mediante a observância do critério da proporcionalidade, ${ }^{55}$ como limite do limite, estruturado em quatro subcritérios. ${ }^{56}$ Concretamente, o bem constitucional colidente como propósito lícito e eventualmente até ordenado constitucionalmente aos órgãos estatais deveria ser perseguido por um meio em si lícito e também adequado e necessário.

\subsubsection{Da licitude do propósito}

Primeiro, requer-se a verificação da licitude - em sentido amplo - do propósito perseguido pelo Poder Público ao restringir o direito fundamental. Questiona-se se o propósito não é vedado pelo ordenamento constitucional. ${ }^{57}$ À pauta vem a promoção de um bem cultural brasileiro como propósito da intervenção anteriormente verificada. Questionável é, contudo, se a fixação de crucifixos em repartições públicas poderia ser enquadrada como bem cultural em sua qualidade de bem jurídico-constitucional, com lastro no art. 216 da CF.

A antropologia, como ramo da ciência que tem como objeto precipuamente o estudo da cultura, fornece alguns critérios para a suposta classificação de um símbolo religioso tal qual o crucifixo como bem cultural de índole constitucional (art. 216, caput, da CF), ao qual o Estado estaria obrigado a garantir o acesso (art. 215, caput, da CF). ${ }^{58}$ Não há consenso a respeito do conceito da cultura e de suas derivações expressamente protegidas segundo o art. 215, caput, da CF da "cultura nacional", incluindo suas "fontes". Porém, alguns de seus elementos constitutivos são aceitos, sem

\footnotetext{
55 A esse respeito, cf. Dimoulis e Martins (2014, p. 176-229) e Pieroth e Schlink (2012, p. 131-150).

56 Sobre os subcritérios da proporcionalidade, há controvérsias na literatura jurídica especializada. Há, em suma, dois posicionamentos. Em primeiro lugar, há o desenvolvido por Pieroth e Schlink (2012, p. 137-151) e repercutido no Brasil por Dimoulis e Martins (2014, p. 168-220), segundo os quais o critério compor-se-ia da verificação prévia da licitude de propósito e meio de intervenção, seguido da avaliação da adequação e necessidade deste em face daquele. Trata-se do método de justificação da intervenção aplicado na presente exposição. Há vários outros entendimentos de inspiração teórica as mais variadas (MARTINS, 2012, p. 7-43), entre os quais aquela sedimentada entre nós e muito recepcionada (em geral sem a devida profundidade) teoria principiológica de marca anglo-saxã e trabalhada para a tradição da civil law por Alexy (2008, p. 116-120). Essa corrente reconhece, sem a rígida disciplina metodológica aqui buscada, o pseudocritério da proporcionalidade em sentido estrito que redunda em incontroláveis ponderações de valores, interesses ou "princípios", que teriam, além da dimensão da validade, justamente a dimensão da importância. Cf. Barroso (2004), por uma adoção da teoria no Brasil, e a crítica circunstanciada de Martins (2012, p. 27 e ss.).

57 Dimoulis e Martins (2014, p. 188-189) explicam que a legitimidade do propósito não reside necessariamente em sua "dignidade constitucional", mas no fato de ele estar conforme a ordem jurídica constitucionalmente compatível.

58 Cf. Querino e Lehfeld (2015, p. 206-207).
} 
desconsiderar seu caráter fluido e incerto. ${ }^{59}$ Outra grande dificuldade que seu estudo revela é a "inconsciência" da cultura, uma vez que o indivíduo, em seu dia a dia, não toma consciência dos costumes que determinam seu comportamento. ${ }^{60}$ Por conseguinte, todas as tentativas de conceituação de cultura acabam sendo amplas e imprecisas. ${ }^{61}$ Consenso há apenas em torno do reconhecimento de que a cultura dirige-se à experiência, à expressão e ao comportamento humanos, condicionando-os na sociedade. ${ }^{62}$ Como forma de culto de uma divindade que impõe uma série de hábitos e condutas e que influencia a ação humana, tendo em vista a relação do homem com o sobrenatural, a religião enquadra-se na cultura de uma sociedade. ${ }^{63}$

A delimitação de um patrimônio cultural dá-se pela tentativa de construção de uma identidade nacional ou de um grupo, abrangendo bens que estabeleçam um vínculo entre indivíduos e coletividade. ${ }^{64}$ Esse processo de determinação do patrimônio cultural é, normalmente, capitaneado pelo Estado por meio de órgãos especificamente criados para servir a essa finalidade. Por meio de entes estatais, busca-se estabelecer um ideário cultural da nação, com o intuito de fomentar a identidade de um povo (CUCHE, 1999, p. 188 e ss.).

Não obstante, essa tentativa vai de encontro à perspectiva atual de que não há sociedades culturalmente homogêneas. Pelo contrário, a "identidade" de uma nação acabaria sendo fragmentada em virtude de sua pluralidade. ${ }^{65}$ Por isso, discute-se atualmente na antropologia o processo de ampliação pelo qual passa o patrimônio cultural de um país para que sejam incluídas também as manifestações culturais passadas e presentes na construção da nação. ${ }^{66}$ Essa transformação incluiria não

\footnotetext{
59 Entre outros, Keesing (1972a, p. 49-50) e Marconi e Presotto (1989, p. 41-44), ao tratarem da questão, fazem referência a uma série de definições distintas sobre cultura. Por sua vez, Kaplan e Manners (1981, p. 15-17) problematizam a definição de cultura, asseverando, contudo, que ela ainda é necessária, entendendo que cultura é o conjunto de fenômenos que englobam comportamentos que não podem ser completamente explicados por conceito psicobiológicos.

60 Nesse sentido, cf. Keesing (1972a, p. 49-50), Herskovits (1963a, p. 37-38) e Cuche (1999, p. 14-15). Gonçalves (2005, p. 19) atribui essa característica também ao patrimônio cultural, cuja classificação como tal independeria da vontade dos órgãos estatais responsáveis, necessitando também de "ressonância" junto ao público.

61 Por exemplo, Tylor (1883, p. 1, tradução livre) entende que cultura é "[...] todo o complexo que inclui o conhecimento, a crença, a arte, a moral, o direito, o costume e qualquer outra capacidade e hábito adquiridos pelo homem enquanto membro da sociedade." Essa definição não está isenta dos problemas listados no texto. No entanto, essa tentativa de conceituação apresenta certo respaldo por alguns autores (KEESING, 1972a, p. 49; HERSKOVITS, 1963a, p. 33; EAGLETON, 2005, p. 5455; MARCONI; PRESOTTO, 1989, p. 41-44). As diferenças entre a abordagem de Tylor e dos demais antropólogos ocorre mais no âmbito de saber se há uma ou mais culturas (universalismo vs particularismo), se elas existiriam em grau de evolução cultural (evolucionismo), sua natureza (ideia, forma de controle, comportamento, etc.), por exemplo. Marconi e Presotto (1989, p. 41-44) separam as conceituações de cultura em vários tipos: as que consideram cultura como um conjunto de ideias, as que compreendem cultura como abstrações de comportamento, as que consideram como comportamento apreendido, as que entendem cultura como um conjunto de mecanismos de controle e as que entendem que a cultura deve ser vista separadamente do ser humano. Além disso, há o uso popular do termo cultura, que a resume à habilidade de um indivíduo nas finuras e nas artes sociais, que não pode ser considerado o sentido dado pela CF, tendo em vista o teor técnico do art. 216, que faz referência a bens materiais e imateriais, bem como lista em seus incisos algumas espécies de bens a serem considerados como patrimônios culturais. Todos eles escapam do sentido comum. Para um estudo das diferenças entre as várias correntes teóricas da antropologia, cf. Cuche (1999, p. 33-46).

62 Nesse sentido, cf. Hoebel (1966, p. 208), Titiev (1963, p. 13), Marconi e Presotto (1989, p. 41-44) e Kaplan e Manners (1981, p. 15-17).

63 Nesse sentido, cf. Herskovits (1963b, p. 139, e ss.), Marconi e Presotto (1989, p. 41-44), Keesing (1972a, p. 48 e ss.) e Keesing (1972b).

64 Nesse sentido, cf. Salaini e Graeff (2011, p. 172-175), Rotman e Castells (2007, p. 59), Gable (2005, p. 52-53), Gonçalves (2005, p. 19), Gonçalves (2007, p. 120), Cuche (1999, p. 28) e Barbalho (2008, p. 89 e ss.).

65 Nesse sentido, cf. Bauman (2012, p. 44-82), Barbalho (2008, p. 95-100) e Boyer (2008, p. 11-14).

66 Igualmente, até mesmo áreas classicamente não consideradas pela antropologia como enquadráveis no conceito de patrimônio cultural são atualmente incluídas nessa categoria (por ex. a gastronomia). Nesse sentido, cf. Rotman e Castells (2007, p. 57-59).
} 
somente os bens selecionados pelo Estado e pelas classes hegemônicas, mas também a necessidade de inserção das classes consideradas "minoritárias". ${ }^{67}$ Isso se dá, pelo fato de que é difícil sustentar, de modo taxativo, uma "unidade" cultural de uma dada sociedade complexa, tendo em vista a diversidade cultural e os muitos povos que a originam. ${ }^{68}$ Esse processo faz com que o patrimônio cultural seja palco de disputas político-ideológicas, em que um grupo pleiteia a proeminência de determinada coletividade em momentos históricos específicos, contestando a identidade cultural considerada como "autêntica" pelos órgãos públicos. ${ }^{69}$

Assim, em qualquer sociedade contemporânea, a busca de uma identidade cultural de uma nação é um processo complexo. Sua verificação precisa observar o rigor metodológico-científico das ciências que dela se ocuparem (antropologia e história, por exemplo). Na esteira de tais reconhecimentos antropológicos, o art. 216 da CF estabelece o conceito constitucional de patrimônio cultural, ${ }^{70}$ incluindo os bens materiais e imateriais ${ }^{71}$ que se refiram à identidade, ação ou memória dos grupos formadores da sociedade brasileira. Além disso, o art. 215, $\mathbb{S} 1^{\circ}$, da CF estabelece ter o Estado o dever de proteger as manifestações culturais populares, indígenas, afro-brasileiras e de outros grupos participantes do processo civilizatório nacional. Atenta ao fato de que a cultura tem caráter multifacetado, podendo uma sociedade albergar várias culturas, a norma constitucional protege todo o patrimônio cultural de todos os grupos étnicos, com suas respectivas religiões, crenças, usos e costumes, que contribuíram em maior ou menor grau para a formação da sociedade brasileira.

Logo, é preciso, primeiro, verificar se o crucifixo enquadrar-se-ia como objeto da tutela constitucional nos termos mencionados; e, segundo, se sua ostentação em repartições públicas faria parte do propósito implícito na proteção do bem jurídico-constitucional assegurado pelo art. 216 da CF.

A primeira mencionada condição está presente. Trata-se do símbolo máximo do cristianismo católico que é, ao lado das liturgias e símbolos de origem africana, a religião mais presente desde a chegada dos primeiros representantes da Coroa Portuguesa em solo sul-americano, mantendo-se, assim, durante toda a história brasileira. Com efeito, membros da Igreja Católica faziam parte da expedição de Cabral. ${ }^{72}$ Durante o Brasil Colônia, teve atuação marcante: citem-se o processo de ca-

\footnotetext{
67 Nesse sentido, cf. Rotman e Castells (2007, p. 59-60), Salaini e Graeff (2011, p. 172, e ss.) e Cuche (1999, p. 188 e ss.).

68 Nesse sentido, cf. Keesing (1972a, p. 68). De modo similar, Titiev (1963, p. 293) afirma que, salvo se usado em sentido figurado, não há uma sociedade inteiramente cristã ou judaica, já que os membros dessas religiões estão presentes em várias nações com padrões culturais distintos. De forma similar, Hoebel (1966, p. 211-214) argumenta que não há uma sociedade totalmente homogênea, havendo normas de comportamento específicas para vários grupos sociais (solteiros x casados; médicos $\mathrm{x}$ advogados, etc.). No caso brasileiro, vários estudos são realizados para a inclusão no patrimônio cultural de certas localidades de bens relacionados a minorias. Nesse sentido, cf. Salaini e Graeff (2011) e Velho (2007).

69 Nesse sentido, cf. Cuche (1999, 188 e ss.); Barbalho (2008, p. 92-100) e Eagleton (2005, p. 60 e ss.). Nesse sentido, cf., também, os casos estudados por Gable (2005), Rotman e Castells (2007), Velho (2007) e Boyer (2008).

70 Em sentido similar, Couto (2015, p. 191) entende que esse preceito constitucional estabelece um conceito jurídico formal de bem cultural.

71 A distinção dos bens entre materiais e imateriais é rejeitada por alguns autores, pois o processo de inventário realizado por órgãos competentes faz com que os bens intangíveis passem por uma "materialização". Nesse sentido, cf. Salaini e Graeff (2011, p. 174-175). Por sua vez, Gonçalves (2005, p. 20 e ss.) considera que a ideia de patrimônio cultural materializa a noção de cultura, que sofreu uma "desmaterialização" no século XX, com a valorização dos bens imateriais. De outra banda, Hoebel (1966, p. 217) considera que a cultura "material" não pode ser chamada de "cultura", pois se trata do produto de uma ação culturalmente determinada.

72 Nesse sentido, cf. Holanda (1976, p. 35-36) e Noronha (2015, p. 94-95).
} 
tequização dos índios realizado pelos jesuítas ${ }^{73}$ e a influência dos jesuítas na arte colonial brasileira. ${ }^{74}$ A proeminência perdurou durante todo o Império, época em que a Igreja Católica era constitucionalmente definida como a religião oficial do Estado, sendo outras religiões tão somente toleradas. Também se estende durante praticamente todo o período republicano, com suas, já, cinco eras constitucionais. ${ }^{75}$ Pesquisas e censos sempre corroboraram a assertiva de o catolicismo continuar sendo a principal religião do País. ${ }^{76}$ Hoje, conta ainda com o maior número de adeptos, apesar do vertiginoso crescimento de denominações protestantes. ${ }^{77,78}$

A presença histórica da Igreja Católica no Brasil, sua inserção no cotidiano do brasileiro e a adoção do catolicismo pela população como sua religião no passado e, em boa parte, também no presente colocam-na, com suas liturgias e símbolos, no "pedestal" de patrimônio cultural do Brasil. ${ }^{79}$ Por outro lado, apesar do reconhecimento tardio, também os símbolos e liturgias das religiões genericamente alcunhadas de afro-brasileiras, como o candomblé, sobretudo em face da grande participação do negro na formação étnica do povo brasileiro, estariam, segundo alguns críticos dessa hegemonia cultural católica, no mesmo patamar do símbolo-mor do catolicismo que é o crucifixo. ${ }^{80}$

Resta saber se o propósito de proteção do patrimônio cultural do art. 216 da CF abarcaria não apenas o reconhecimento do crucifixo como bem cultural, mas também abrangeria a determinação constitucional de sua fixação nas repartições públicas do Estado. Por ser o crucifixo também um símbolo religioso em sentido estrito, não há como não se trazer à pauta, aqui, também, a norma constitucional do art. 19, I, da CF que é, inclusive, lex specialis em relação ao art. 216 da CF, tendo em tese, sabidamente, o condão de afastar a aplicação deste quando concorrerem na regulamentação de um hipótese fática. O art. 19, I, da CF veda ao Estado beneficiar cultos religiosos e igrejas ou atrapalhar o seu funcionamento, salvo se para a colaboração de interesse público. Vedadas são, igualmente, relações de aliança ou dependência. Objetivamente, decorre do art. 19, I, da CF o caráter laico do Estado brasileiro, ${ }^{81}$ que, jusfundamentalmente falando, pode completar a proteção de dimensão jurídico-subjetiva. Esse complemento propiciado pelo referido princípio jurídico-objetivo da laicidade do Estado fortalece o princípio de não intervenção nos comportamentos abrangidos pela área de pro-

\footnotetext{
73 Nesse sentido, cf. Holanda, (1973, p. 51-75) e Noronha (2015, p. 95).

74 Cf. Noronha (2015, p. 95).

75 A esse respeito, Leite (2011, p. 32) considera que a Constituição de 1891 estabeleceu efetivamente uma separação entre Estado e Igreja, enquanto a Constituição de 1934 mudou o modelo para uma cooperação entre Estado e Igreja por pressão da Igreja Católica. Contudo, o autor considera que, mesmo no caso da Constituição de 1891, havia uma grande proximidade entre a religião católica e os membros do Estado, considerando a esmagadora maioria de católicos na população brasileira. Em sentido similar, cf. Giumbelli (2008 p. 82).

76 Cf. Ribeiro (1982, p. 275-276) analisa os censos de 1940, 1950 e 1970, os quais demonstram uma predominância do catolicismo na população brasileira nesses anos, em que, respectivamente, 95,01\%, 93,49\% e 91,80\% do povo brasileiro considerava-se católico.

77 Nesse sentido, ver dados do Censo 2010 em: <http://censo2010.ibge.gov.br/> Acesso em: 13 jan. 2016.

78 Rocha e Vásquez (2014, p. 23 e ss.) defendem que, apesar da hegemonia cultural do catolicismo desde o Descobrimento, há um crescimento das opções religiosas no Brasil, que seria resultado da "fertilização cruzada" entre as religiões de origem indígena, africana e do catolicismo português. Análise semelhante é o estudo de Ribeiro (1982, p. 275 e ss.), que demonstra a diminuição do catolicismo em face de outras religiões.

79 Ribeiro (1995, p. 37-41, 56-63) demonstra, ao analisar as matrizes étnicas que formaram o povo brasileiro, o papel que a Igreja Católica teve nesse processo. Ao mesmo tempo, destaca como o objetivo de juntar todos os homens em uma só cristandade impulsionou a expansão marítima portuguesa e a catequização dos índios.

80 Nesse sentido, cf. Velho (2007, passim).

81 Sobre a laicidade do Estado e na CF/88, cf. Sarmento (2007, p. 2 e ss.).
} 
teção do art. 5, VI e VIII, da CF, incluindo a não intervenção na sua modalidade de exercício negativo e o tratamento estatal igual devido a todas as crenças.

Em razão desse reforço de proteção, o art. 19, I, da CF pode ser aplicado com a técnica da combinação ("art. 19, I c.c. e art. 5, VI e VIII") no âmbito das organizações religiosas, que podem ser, extraordinariamente, titulares de um direito fundamental. $\mathrm{O}$ Estado não pode "embaraçar" o funcionamento das igrejas e cultos. ${ }^{82}$ Deve tratamento igualitário a todas elas e, destarte, também às pessoas jurídicas que dão forma a um modo de exercício do direito fundamental. Especificamente, deriva do art. 19, I, da CF mais uma relevante vedação destinada ao Estado, qual seja, a de estabelecer e subvencionar qualquer igreja. Tal vedação desdobra-se na proibição de promoção de qualquer igreja mediante divulgação ou proselitismo estatal em prol de determinada instituição religiosa. Destarte, a vedação encerra o direito de cada titular do direito fundamental a resistir em sentido lato a tratamentos desiguais, à criação de vantagens em face de outras crenças. ${ }^{83}$ Por fim, trata-se de assegurar a observância do princípio da neutralidade ética do Estado, que, na Alemanha, é uma construção jurisprudencial realizada pelo TCF por meio da interpretação do art. 4, I, da Grundgesetz (GG) c.c. outros vários dispositivos da Grundgesetz ${ }^{84}$ e da Constituição da República de Weimar, recepcionada por aquela no que tange à disciplina da liberdade confessional e de consciência do próprio art. 4, I, da Grundgesetz.

No caso em tela, há a exposição pelo Estado de um símbolo religioso de uma única entidade religiosa. Essa exposição somente poderia ser justificada constitucionalmente, e, ainda assim, apenas em tese, pois caberia, ainda, cumprir o ônus argumentativo pelo Estado uma vez que direitos fundamentais individuais foram atingidos, se pudesse ser enquadrada na ressalva prevista no final do art. 19, I, CF, da "colaboração de interesse público". Presente estaria uma hipótese de direito constitucional colidente, primeiro apenas formalmente idôneo a justificar a verificada intervenção no direito fundamental individual e correspondente constatação da licitude do propósito.

Todavia, a referida hipótese notoriamente não está presente no caso em apreço. A suposta "colaboração de interesse público" não tem sequer o condão de indiciar que a ostentação de um símbolo religioso de uma única entidade religiosa em repartições públicas corresponda à vontade do constituinte. $\mathrm{O}$ art. 19, I, in fine, aplica-se a constelações fáticas totalmente diversas daquela. Cite-se, como exemplo, a assistência religiosa do art. $5^{\circ}$, VII, da CF como direito prestacional, no serviço de assistência a desamparados, vulneráveis ou vítimas de catástrofes. Também tais colaborações de caráter pontual devem ser, no que se refere à política estatal, ética e religiosamente neutras; ou, no campo religioso em sentido estrito, no máximo ecumênicas. Nesse sentido, somente em havendo

\footnotetext{
82 Somente se chega a essa conclusão se se considerar que as igrejas e cultos, como pessoas jurídicas, são titulares de direitos fundamentais. Apesar de a redação do art. $5^{\circ}$, caput, da CF não ser expressa a esse respeito, tem-se aceitado essa titularidade. A respeito dessa questão, cf. Dimoulis e Martins (2014, p. 83-85), Marmelstein (2013, p. 231-232), Mendes e Branco (2011, p. 195-196), Sarlet, Marinoni e Mitidiero (2012, p. 310-313) e Sarlet (2010, p. 222-224).

83 Sarmento (2007, p. 3 e ss.) relaciona a laicidade do Estado com a proteção de dois direitos fundamentais: a liberdade de crença e a igualdade. $\mathrm{O}$ autor sustenta que o favorecimento de uma religião implica uma desvantagem das demais crenças religiosas do país em violação da igualdade.

84 O TCF elenca também o direito fundamental à igualdade (art. 3, III, e o art. 33, I, GG) e o art. 140 da GG, além dos art. 136, I e IV, e art. 137, I, da Constituição da República de Weimar. Nesse sentido, cf. Martins (2005, p. 370).
} 
convite a representantes do maior número possível de líderes de orientações das mais variadas crenças, restaria respeitado o princípio do Estado laico do art. 19, I, da GG e a liberdade de crença do art. 5, VI, de todos os envolvidos.

Por fim, tal colaboração precisaria ser detalhadamente regulamentada por lei para assegurar que fique dentro do quadro constitucional descrito. Portanto, conclui-se que na tradição sem lastro legal de se dependurar crucifixos em paredes de repartições públicas não há colaboração no sentido do art. 19, I, in fine, da CF.

Não tendo como se subsumir o propósito implícito na afixação de crucifixos em paredes de repartições à proteção de um bem jurídico-constitucional colidente, resta injustificada a intervenção estatal na liberdade religiosa e, por via de consequência, inconstitucional em face do art. $5^{\circ}$, VI, da CF.

Como podem persistir dúvidas quanto à conclusão pela não presença de um bem jurídico-constitucional colidente no propósito perseguido pelos órgãos estatais que mantenham, sem amparo legal, crucifixos em paredes das repartições estatais, concessivamente (mais uma vez), avança-se a seguir no exame de proporcionalidade, investigando-se a relação meio-fim implícita na intervenção estatal.

\subsubsection{Da licitude do meio}

No tocante ao segundo subcritério, o da licitude do meio, deve-se verificar apenas se se está diante de um meio não expressamente vedado pela ordem jurídica nacional. ${ }^{85}$ A fixação de crucifixos em tese não atenta contra nenhuma norma constitucional ou ordinária. Questionável seria se não teria havido violação do princípio da legalidade do art. 37, caput, da CF, tendo em vista a ausência de lastro legal. Também aqui, concessivamente, admite-se a presença da licitude do meio de intervenção.

\subsubsection{Da adequação do meio utilizado}

Pelo subcritério da adequação, investiga-se se há entre a situação efetivamente criada pelo Estado mediante a intervenção e a situação idealizada uma conexão firmada em hipóteses comprovadas sobre a realidade empírica. ${ }^{86}$ Diz-se que o meio utilizado pelo Estado deve "fomentar" o propósito da intervenção, porque se trata do estabelecimento de um prognóstico de base empírica.

No caso em tela, trata-se de se averiguar se essa relação de fomento entre a exibição do crucifixo nas repartições públicas e a realização do propósito de promover um bem cultural brasileiro poderia ser estabelecida.

A divulgação de um determinado bem ou obra é forma comum de promoção da cultura de uma dada sociedade. Por meio da visualização de determinado objeto, constatam-se e incorporam-se potencialmente seus elementos. Esse é o mesmo princípio que se tem, por exemplo, na promoção de exibições de obras de arte ou na preservação de edifícios históricos. A promoção de tais atos por

85 Cf. Dimoulis e Martins (2014, p. 200-203).

86 Cf. Dimoulis e Martins (2014, p. 203 e ss.). 
algum órgão público permite aos indivíduos observarem os respectivos bens, possibilitando a assimilação de suas essências.

A fixação de um crucifixo em repartições públicas para a contemplação daqueles que, diariamente, realizam algum ato ou negócio com o Poder Público fomenta o propósito da promoção do bem jurídico-constitucional do patrimônio cultural, porque, invariavelmente, haverá o confronto com o símbolo. Como já exposto, a duração de tal influência está condicionada ao prolongamento das tratativas entre o particular e a Administração Pública, mas a provável efemeridade não tem o condão de afastar a adequação do meio de intervenção em face de seu propósito anteriormente verificado.

\subsubsection{Da necessidade do meio utilizado}

O último subcritério da proporcionalidade observa-se pela busca de alternativas igualmente adequadas, mas potencialmente menos onerosas para o exercício do direito fundamental. Trata-se de saber se não se está restringindo-o demasiadamente, o que ocorreria se existissem meios que também fomentassem o propósito, mas que não limitassem o direito fundamental de maneira tão intensa (menor onerosidade possível dentre os meios idôneos ou adequados).

No caso em tela, há uma intervenção intensa, porquanto inevitável. Embora o tempo de duração da influência do crucifixo sobre o titular do direito fundamental seja variável, não pode ser afastada pelo indivíduo. Logo, ele sempre terá de se submeter à intervenção, principalmente por se tratar de locais que, em regra, prestam serviços públicos essenciais. Portanto, tal imposição pode ser rápida, como na hipótese de um entregador que precisa deixar determinada encomenda em uma repartição ou pode ser reiterada e prolongada, como no caso de um advogado que precisa ir, diariamente, a um juízo em que haja um crucifixo fixado na parede. Assim, a intensidade pode ser mais acentuada ou não, mas sempre existirá.

A promoção da cultura da sociedade brasileira pode se dar por uma série de meios de intervenção alternativos igualmente adequados, mas menos intensos. Nesse sentido, imagine-se a promoção de exibições e eventos culturais em que os indivíduos possam optar ou não por frequentar. Logo, não existiria a inevitabilidade característica do caso dos crucifixos (ainda que novamente questionáveis em face do art. 19, I, da CF, o que não precisa ser ora examinado). Também a participação na não obrigatória aula de religião no plano pedagógico de escolas públicas ou privadas sob fiscalização do MEC persegue o escopo de promover a cultura (art. 210, $\mathbb{\$} 1^{\circ}$, da CF). Esses meios são notoriamente menos onerosos, impugnando definitivamente a necessidade da fixação dos crucifixos em paredes de repartições públicas.

O elemento da inevitabilidade, bastante investigado na supracitada decisão do TCF alemão (Kruzifix-Urteil), é central para o estabelecimento da diferença na avaliação da intensidade da intervenção. Parâmetro para a intensidade é a sensibilidade do titular do direito atingido e não a rason d'Etat. Eis o caráter racional-jurídico do critério da proporcionalidade no contexto justeórico liberal em contraposição à ponderação de valores ou princípios, adotada por algumas correntes teóricas. $\bigcirc$ 
TCF alemão considerou que esse caráter, quando conjugado com outras peculiaridades, ${ }^{87}$ tornava o enunciado normativo inconstitucional por violar a liberdade religiosa em sua dimensão negativa.

Portanto, mesmo se o propósito e o meio em si fossem lícitos - o que fora anteriormente impugnado - a prática em comento constitui-se em uma intervenção adequada, mas não necessária, no direito fundamental à liberdade de crença. Destarte, ela não é justificada constitucionalmente. Consequentemente, também por esse viés viola o art. $5^{\circ}$, VI, da CF.

\section{Conclusão}

A polêmica da fixação dos crucifixos em repartições públicas não se restringe somente à laicidade do Estado. Como demonstrado, tal prática comum nas repartições públicas brasileiras tem de ser questionada quanto à sua constitucionalidade por força do direito fundamental à liberdade de crença do art. $5^{\circ}$, VI, da CF.

Entre os comportamentos resguardados em face dos órgãos dos três poderes estatais pelo direito fundamental à liberdade religiosa, encontra-se a faculdade individual de acreditar e aceitar como especiais quaisquer práticas e símbolos relativos à crença do titular do direito. Como qualquer outro direito fundamental, também a liberdade de crença pode ser exercida negativamente, no sentido de se negar ou não se submeter a atos, práticas e símbolos estranhos à própria convicção religiosa, bem como o direito à negação de qualquer religiosidade (ateísmo).

Por isso, a fixação de crucifixos em repartições públicas caracteriza-se como uma intervenção do Estado no direito fundamental à liberdade de crença, que precisa ser justificada constitucionalmente. Inexistindo qualquer amparo legal para esse ato, já se violou o princípio da legalidade da Administração e a necessidade de o direito fundamental somente ser restringido por lei, indicando, reflexamente, sua inconstitucionalidade também em face do direito fundamental em comento. Mesmo quando se toma o leviano argumento (não fundamentado) usado na referida decisão do CNJ e chanceladora de tal prática, ampliando-se o exame de constitucionalidade do ato em face de sua licitude em sentido amplo, a prática já resta inconstitucional por ausência, até mesmo, de um propósito correspondente à proteção de um bem jurídico-constitucional. Ainda que estivesse presente tal condição, trata-se de uma intervenção adequada, mas não necessária no direito fundamental à liberdade de crença, principalmente em sua acepção de exercício negativo. Isso ocorre pelo fato de a confrontação com o símbolo religioso ser inevitável e imposta sempre que o indivíduo tenha de ir a uma repartição pública.

A relevância histórico-cultural do cristianismo para a sociedade brasileira é inegável, assim como a proeminência do catolicismo em termos de número de seguidores. Porém, dentro do Estado Democrático de Direito impõe-se o constante e - de preferência - espontâneo e preventivo respeito aos direitos fundamentais do indivíduo e ao princípio jurídico-objetivo do pluralismo, que, a exem-

87 Duração da exposição ao símbolo religioso, indivíduos sujeitos à exposição (crianças), por exemplo. Por uma análise do caso, cf. Martins (2005, p. 366-378). 
plo daqueles, tem lastro constitucional positivo (vide, por exemplo, o art. $1^{\circ}$, V, da CF). Esse processo deve ter por base a promoção do bem de todos e pode suscitar decisões contramajoritárias erga omnes impostas pelos órgãos judiciais titulares da função jurisdicional-constitucional.

Portanto, por mais historicamente relevante que possa ser, ou mesmo correspondente aos anseios da maioria da população brasileira, o crucifixo como símbolo religioso dependurado em paredes de repartições públicas representa uma violação do direito fundamental à liberdade de crença (art. 5, VI) e do mandamento de Estado laico (art. 19, I, da CF).

\section{Referências}

ALEXY, Robert. Teoria dos Direitos Fundamentais. Tradução Virgílio Afonso da Silva. São Paulo: Malheiros, 2008.

BARBALHO, Alexandre. Textos nômades: política, cultura e mídia. Fortaleza: Banco do Nordeste do Brasil, 2008.

BARROSO, Luís Roberto. Interpretação e Aplicação da Constituição. 6. ed. São Paulo: Saraiva, 2004.

BASTOS, Celso Ribeiro; MARTINS, Ives Gandra. Comentários à Constituição do Brasil. São Paulo: Saraiva, 1989. v. 2.

BASTOS, Celso Ribeiro; MARTINS, Ives Gandra; MEYER-PFLUG Samantha. Do direito fundamental à liberdade de consciência e de crença. In: PIOVESAN, Flávia; GARCIA, Maria (Org.). Coleção Doutrinas Essenciais: Direitos Humanos - Direitos Civis e Políticos. São Paulo: Revista dos Tribunais, 2011. v. 2.

BAUMAN, Zygmunt. Ensaios sobre o conceito de cultura. Tradução Carlos Alberto Medeiros. Rio de Janeiro: Zahar, 2012.

BOYER, Véronique. Passado português, presente negro e indizibilidade ameríndia: o caso de Magazão Velho, Amapá. Religião e Sociedade, Rio de Janeiro, v. 28, n. 2, p. 11-29, 2008.

BRASIL. Conselho Nacional de Justiça. Pedido de Controle Administrativo n. 1418. Relator: Conselheiro Emmanoel Campelo. Julgamento em 24 maio 2016. Disponível em: <http://ujucasp.org. br/imprensa/noticias_publicadas/Decisao-do-CNJ-sobre-crucifixos-nas-salas-do-Poder-Judiciario. pdf >. Acesso em: 18 jul. 2016.

BRASIL. Conselho Nacional de Justiça. Pedido de providências n. 1344. Relator: Oscar Argollo. Julgamento em 06 jun. 2007. Disponível em: <http://www.cnj.jus.br/acompanhamentoprocessualportal/>. Acesso em: 13 jan. 2016.

BRASIL. Conselho Nacional de Justiça. Recurso administrativo no Pedido de Providências n. 0001859 66.2009.2.00.0000. Relator: Cons. Paulo de Tarso Tamburini Souza. Julgamento em 09 jun. 2009. Disponível em: <https://www.cnj.jus.br/ecnj/>. Acesso em: 13 jan. 2016.

BRASIL. Ministério Público de São Paulo. Petição n. 48723/07. Conselho Superior do Ministério Público. Relator: Cons. Walter Paulo Sabella. Julgamento em 27 ago. 2007. Disponível em: <http:// www.mpsp.mp.br/portal/page/portal/noticias/publicacao_noticias/2007/setembro/448FF05F79E72FEBE040A8C02C013604>. Acesso em: 13 jan. 2016. 
BRASIL. Tribunal de Justiça do Rio Grande do Sul. Expediente Administrativo Processo n. 013911/000348-0. Relator: Des. Cláudio Baldino Maciel. Conselho da Magistratura. Julgamento em 06 mar. 2012. Disponível em: <http://www.tjrs.jus.br/site/jurisprudencia/jurisprudencia_administrativa/ >. Acesso em: 13 jan. 2016.

CANOTILHO, José Joaquim Gomes. Direito Constitucional e Teoria da Constituição. 7. ed. Coimbra: Almedina, 2000.

CARVALHO FILHO, José do Santos. Manual de Direito Administrativo. 11. ed. Rio de Janeiro: Lumen Juris, 2004.

COUTO, Reinaldo. Patrimônio cultural artístico. In: MAMEDE, Gladston; FRANCA FILHO, Marcílio Toscano; RODRIGUES JÚNIOR, Otávio Luiz (Org.). Direito da Arte. São Paulo: Atlas, 2015. p. 189-208.

CUCHE, Denys. A noção de cultura nas ciências sociais. Tradução Viviane Ribeiro. Bauru: Edusc, 1999.

DIMOULIS, Dimitri. Manual de Introdução ao Estudo do Direito. 4. ed. rev., atual. e ampl. São Paulo: Revista dos Tribunais, 2011.

DIMOULIS, Dimitri; MARTINS, Leonardo. Teoria Geral dos Direitos Fundamentais. 5. ed. rev., atual. e ampl. São Paulo: Atlas, 2014.

DI PIETRO, Maria Sylvia Zanella. Direito Administrativo. 27. ed. São Paulo: Atlas, 2014.

EAGLETON, Terry. A Idéia de Cultura. Tradução Sandra Castello Branco. São Paulo: Ed. Unesp, 2005.

FAORO, Raymundo. Os Donos do Poder: formação do patronato político brasileiro. 6. ed. Rio de Janeiro: Globo, 1984. v. 1.

FREITAS, Juarez. O controle dos atos administrativo e os princípios fundamentais. 4. ed. rev. e ampl. São Paulo: Malheiros, 2009.

GABLE, Eric. What heritage does and does not to identity: some answers from an ethnographic perspective. Horizontes Antropológicos, Porto Alegre, ano 11, i. 23, p. 51-70, jan./jun. 2005.

GIUMBELLI, Emerson. A presença do religioso no espaço público: modalidades no Brasil. Religião e Sociedade, Rio de Janeiro, v. 28, n. 2, p. 80-101, 2008.

GONÇALVES, José Reginaldo Santos. Autenticidade, memória e ideologias nacionais: o problema dos patrimônios culturais. In: GONÇALVES, José Reginaldo Santos (Org.). Antropologia dos Objetos: coleções, museus e patrimônios. Rio de Janeiro, 2007. p. 117-138.

GONÇALVES, José Reginaldo Santos. Ressonância, materialidade e subjetividade: as culturas como patrimônios. Horizontes Antropológicos, Porto Alegre, ano 11, n. 23, p. 15-36, jan./jun. 2005.

HERSKOVITS, Melville J. Man and his Works: antropologia cultural. Tradução Maria José de Carvalho e Hélio Bichels. 8. ed. São Paulo: Mestre Jou, 1963a. v. 1. 
HERSKOVITS, Melville J. Man and his Works: antropologia cultural. Tradução Maria José de Carvalho e Hélio Bichels. 8. ed. São Paulo: Mestre Jou, 1963b. v. 2.

HESSE, Konrad. Elementos de Direito Constitucional da República Federal da Alemanha. Tradução Luís Afonso Heck. Porto Alegre: Sérgio Antonio Fabris Editor, 1998.

HOEBEL, Edward Adamson. A natureza da cultura. In: SHAPIRO, Harry L. (Org.). Homem, Cultura e Sociedade. Rio de Janeiro: Fundo de Cultura, 1966. p. 208-222.

HOLANDA, Sergio Buarque de (Coord.). História Geral da Civilização Brasileira: A época colonial Administração, economia e sociedade. 3. ed. São Paulo: Difusão Europeia do Livro, 1973. v. 2.

HOLANDA, Sergio Buarque de (Coord.). História Geral da Civilização Brasileira: A época colonial Do descobrimento à expansão territorial. 5. ed. São Paulo: Difel, 1976. v. 1.

HOLANDA, Sergio Buarque de (Coord.). Raízes do Brasil. 26. ed. São Paulo: Companhia das Letras, 1995.

KEESING, Felix M. Antropologia Cultural. Tradução José Veiga. 2. ed. Rio de Janeiro: Fundo de Cultura, 1972a. v. 1.

KEESING, Felix M. Antropologia Cultural. Tradução Waltensir Dutra. 2. ed. Rio de Janeiro: Fundo de Cultura, 1972b. v. 2.

JUSTEN FILHO, Marçal. Curso de Direito Administrativo. 8. ed. Belo Horizonte: Fórum, 2012.

KAPLAN, David; MANNERS, Robert A. Teoria da Cultura. 2. ed. Tradução Zilda Kacelnik. Rio de Janeiro: Zahar, 1981.

LEITE, Fábio Carvalho. O laicismo e outros exageros sobre a primeira República no Brasil. Religião e Sociedade, Rio de Janeiro, v. 31, n. 1, p. 32-60, 2011.

MARCONI, Marina de Andrade; PRESOTTO, Zélia Maria Neves. Antropologia: uma introdução. 2. ed. São Paulo: Atlas, 1989.

MARMELSTEIN, George. Curso de Direitos Fundamentais. 4. ed. São Paulo: Atlas, 2013.

MARTINS, Leonardo. Cinquenta Anos de Jurisprudência do Tribunal Constitucional Federal Alemão. Montevideo: Konrad Adenauer Stiftung, 2005.

MARTINS, Leonardo. Direito Processual Constitucional Alemão. São Paulo: Atlas, 2011.

MARTINS, Leonardo. Liberdade e Estado Constitucional: leitura jurídico-dogmática de uma complexa relação a partir da teoria liberal dos direitos fundamentais. São Paulo: Atlas, 2012.

MELLO, Celso Antônio Bandeira de. Curso de Direito Administrativo. 25. ed. São Paulo: Malheiros, 2008.

MENDES, Gilmar Ferreira; BRANCO, Paulo Gustavo Gonet. Curso de Direito Constitucional. 6. ed. São Paulo: Saraiva, 2011.

MIRANDA, Jorge. Manual de Direito Constitucional. 3. ed. Coimbra: Coimbra Editora, 2000. 
MIRANDA, Pontes de. Comentários à Constituição de 1946. Rio de Janeiro: Henrique Cahen Editor, 1947. v. 3.

NORONHA, Ibsen. Considerações sobre direito, arte e religião. In: MAMEDE, Gladston; FRANCA FILHO, Marcílio Toscano; RODRIGUES JÚNIOR, Otávio Luiz (Org.). Direito da Arte. São Paulo: Atlas, 2015. p. 87-116.

NOVELINO, Marcelo. Manual de Direito Constitucional. 8. ed. rev. e atual. São Paulo: Método, 2013.

NOWAK, John E.; ROTUNDA, Ronald D. Principles of Constitutional Law. St. Paul: West, 2007.

PIEROTH, Bodo et al. Grundrechte. Staatsrecht II. 31. ed. Heildelberg: C.F. Müller, 2015.

PIEROTH, Bodo; SCHLINK, Bernhard. Direitos Fundamentais. Tradução António Francisco de Sousa e António Franco. São Paulo: Saraiva, 2012.

QUERINO, Ana Célia; LEHFELD, Lucas de Souza. Os direitos culturais na ordem constitucional: uma análise das Emendas Constitucionais 42/2003, 48/2005 e 71/2012. Revista de Direito Constitucional e Internacional, São Paulo, v. 90, p. 201-214, jan./mar. 2015.

RIBEIRO, Darcy. O Povo Brasileiro: a formação e o sentido do Brasil. 2. ed. São Paulo: Companhia de Letras, 1995.

RIBEIRO, René. Antropologia da Religião e Outros Estudos. Recife: Massangana, 1982.

ROCHA, Cristina; VÁSQUEZ, Manuel A. O Brasil na nova cartografia global da religião. Religião e Sociedade, Rio de Janeiro, v. 34, n. 1, p. 13-37, jun. 2014.

ROTMAN, Mônica; CASTELLS, Alícia Norma González de. Patrimônio e cultura: processos de politização, mercantilização e construção de identidades. In: LIMA FILHO, Manuel Ferreira; ECKERT, Cornélia; BELTRÃO, Jane Felipe (Org.). Antropologia e patrimônio cultural: diálogos e desafios contemporâneos. Blumenau: Nova Letras, 2007. p. 57-79.

SALAINI, Cristian Jobi; GRAEFF, Lucas. A respeito da materialidade do patrimônio imaterial: o caso do INRC Porongos. Horizontes Antropológicos, Porto Alegre, ano 17, n. 36, p. 171-195, jul./dez. 2011.

SANTOS JÚNIOR, Aloísio Cristovam dos. A interferência do judiciário nos assuntos internos das organizações religiosas: quais os limites? Espaço Jurídico, Joaçaba, v. 11, n. 1, p. 37-62, jan./jun. 2010.

SARLET, Ingo Wolfgang. A eficácia dos direitos fundamentais. 10. ed. rev., atual. e ampl. Porto Alegre: Livraria do Advogado, 2010.

SARLET, Ingo Wolfgang; MARINONI, Luiz Guilherme; MITIDIERO, Daniel. Curso de Direito Constitucional. 1. ed. São Paulo: Revista dos Tribunais, 2012.

SARMENTO, Daniel. O crucifixo nos tribunais e a laicidade do Estado. Revista Eletrônica PRPE, ano 5, maio 2007. Disponível em: <http://www.prpe.mpf.mp.br/internet/index.php/internet/Legislacao-e-Revista-Eletronica/Revista-Eletronica/2007-ano-5/(offset)/10>. Acesso em: 18 jul. 2016. 
SILVA, José Afonso da. Curso de Direito Constitucional Positivo. 33. ed. São Paulo: Malheiros, 2009.

SILVA, Virgílio Afonso da. Direitos Fundamentais: conteúdo, essencial, restrições e eficácia. 2. ed. São Paulo: Malheiros, 2011.

TAVARES, André Ramos. Paradigmas do Judicialismo Constitucional. São Paulo: Saraiva, 2012.

TITIEV, Mischa. Introdução a Antropologia Cultural. Tradução João Pereira Neto. 2. ed. Lisboa: Fundação Calouste Gulbenkian, 1963.

TYLOR, Edward B. Researches into the development of mythology, philosophy, religion, language, art and custom. New York: Henry Hold and Company, 1883.

VELHO, Gilberto. Patrimônio, negociação e conflito. In: LIMA FILHO, Manuel Ferreira; ECKERT, Cornélia; BELTRÃO, Jane Felipe (Org.). Antropologia e Patrimônio Cultural: Diálogos e desafios contemporâneos. Blumenau: Nova Letras, 2007. p. 249-261.

WEINGARTNER NETO, Jayme. Liberdade religiosa na Constituição: fundamentalismo, pluralismo, crenças e cultos. Porto Alegre: Livraria do Advogado, 2007.

Data da submissão: 11 de abril de 2016 Avaliado em: 04 de julho de 2016 (AVALIADOR A) Avaliado em: 15 de julho de 2016 (AVALIADOR B) Aceito em: 03 de novembro de 2016 